\title{
A retrospective investigation into the outbreaks of abortions and orchitis in livestock in Namibia
}

\author{
Alaster Samkange ( $\sim$ alastersamkange@gmail.com ) \\ University of Namibia https://orcid.org/0000-0003-0646-6250 \\ Jolandie van der Westhuizen \\ University of Namibia
}

Anselm Siegfried Voigts

University of Namibia

Frank Chitate

University of Namibia

Israel Kaatura

University of Namibia

Siegfried Khaiseb

University of Namibia

Emmanuel H. Hikufe

University of Namibia

Juliet Kabajani

University of Namibia

Alec S. Bishi

University of Namibia

Pricilla Mbiri

University of Namibia

Ndahafa N. Hawanga

University of Namibia

Borden Mushonga

University of Namibia

\section{Research Article}

Keywords: abortions, orchitis, outbreak, investigation, Namibia

Posted Date: March 3rd, 2022

DOI: https://doi.org/10.21203/rs.3.rs-1221209/v1 
License: (c) (i) This work is licensed under a Creative Commons Attribution 4.0 International License. Read Full License 


\section{Abstract}

This study investigated outbreaks of seemingly related abortions and orchitis which occurred in Namibia from 2016 to 2018. A combination of epidemiological studies (using questionnaires), necropsies, microbiology, serology, molecular biological techniques like PCR and mineral analytical techniques were used in an attempt to establish the aetiology of these abortion and orchitis outbreaks. The results showed that the outbreaks were limited to Namibia's east and central regions and mainly occurred on farms that reared cattle, sheep and goats and on farms with a mixture of these species. In some cases, horses and game species were also affected. Gross pathological findings included testicular enlargement, with focal haemorrhages and soft to hard testicular consistency in males. Histopathological findings included severe chronic orchitis, testicular degeneration, prominent interstitial mononuclear inflammatory cell infiltration with a few multinucleated inflammatory cells. In samples obtained from aborted fetuses, significant histopathological findings included meconium aspiration, funisitis, placentitis and cardiomyopathy in fetal tissues, whereas endometritis was the primary pathology observed in females. Brucella spp., Enterococcus spp., Escherichia coli, Streptococcus spp., Truperella pyogenes, micronutrient imbalances toxic and pathogenic abiotic nanoparticles which resulted from drought conditions that preceded these outbreaks, were identified as possible causes.

\section{Introduction}

Tibary generically defines abortion as the artificial termination of pregnancy before the foetus is viable and after organogenesis has been completed (Tibary 2021). In cattle, abortion is defined as an expulsion of a non-viable fetus between days 43 and 260 of pregnancy, whilst stillbirth is the expulsion of a fetus after gestation day equal to or greater than 260 days (Wolf-Jäckel et al. 2020). Causes of livestock abortions can be classified into infectious and non-infectious causes, including physical, chemical and biological causes. Chemical causes include nutritional and toxic, while biological non-infectious causes include genetic, hormonal, immunological and iatrogenic (Derdour et al. 2017; Ghalmi et al. 2009).

In general, infectious causes of abortions include bacterial, viral, protozoal or mycotic causes (Parkinson et al. 2019). Specifically, infectious causes of abortion in cattle and small ruminants (sheep and goats) include viruses, bovine herpesvirus 1 (IBR/IPV) (Vermunt et al. 2019), bovine herpesvirus 4 (Derdour et al. 2017), bovine viral diarrhoea virus -1 (BVDV) (Bulut et al. 2017; Derdour et al. 2017; Tulu et al. 2018), bluetongue, Akabane virus (Parkinson et al. 2019), Rift Valley fever (Gerdes 2004), Q-fever (Bishi et al. 2018; Derdour et al. 2017; Tulu et al. 2018), Schmallenberg virus (Molini et al. 2018; Sibhat et al. 2018) and Border disease virus (Dun 2019). Bacterial causes of abortion in cattle and small ruminants include; Leptospira interrogans serovar Hardjo (Derdour et al. 2017; Grooms 2006; Tulu et al. 2018), brucellosis (Derdour et al. 2017; Ndazigaruye et al. 2018; Tulu et al. 2018, 2020), listeriosis (Tulu et al. 2018), Salmonella Dublin (Derdour et al. 2017; Dun 2019), Campylobacter jejuni (Dun, K. 2019) and Chlamydophila (Chlamydia) abortus (Dun 2019; Samkange et al. 2010). Protozoal causes include Neospora caninum (Derdour et al. 2017; McAllister 2020; Reichel et al. 2013; Tulu et al. 2018), 
trichomoniasis (Dąbrowska et al. 2019). In addition, Aspergillus fumigatus has also been reported to cause abortions (Tulu et al. 2018).

In addition to abortions, Chlamydophila (Chlamydia) abortus, Truepella pyogenes (Ponnusamy et al. 2017), Brucella spp. (Saxena et al. 2018) and Corynebacterium pseudotuberculosis can also cause epididymitis and orchitis (Bell 2006; Kováčová et al. 2007; Stewart et al. 2018; Umer Chhalgari et al. 2017). Actinobacillus seminis is also known to cause epididymo-orchitis in both rams and bucks (Dos Santos et al. 2014), while Salmonella enterica serovar Typhimurium caused epididymo-orchitis in a bull (Mahmoud et al. 2020).

From 1991 to 1992 the country had an outbreak of abortions, stillbirths and neonatal deaths in cattle, sheep and goats on 119 commercial farms in the central regions (P.A. Basson, unpublished information). The bacterium Enterococcus casseliflavus was the primary pathogen isolated in 30 out of the 91 specimens which were tested. However, experimental inoculation of this bacterium into pregnant cows did not cause abortions (P.A. Basson, unpublished data). From late 2016 until early 2018 many farms in the central regions of Namibia experienced outbreaks of abortions and orchitis in cattle, sheep and goats. These were so widespread and caused very high reproductive losses, which in turn caused an outcry in the country to such an extent that it ended up making news headlines in the local press (Staff Reporter 2017).

The primary objective of this paper was to investigate the possible causes of the outbreaks of abortion associated with orchitis that occurred in the central regions of Namibia from 2016 to 2018 in cattle, sheep and goats by collating and analyzing all available data and information.

\section{Materials And Methods}

\section{Study area}

The study area included some commercial farms in Khomas, Omaheke and Otjozondjupa regions of Namibia.

\section{Study animals}

The study animals included all breeding cattle (Bos taurus), sheep (Ovis aries) and goats (Capra aegagrus hircus) in the affected regions, which experienced reproductive losses in the form of abortions, stillbirths, orchitis or epididymo-orchitis.

\section{Data collection}

Questionnaires were administered at 50 commercial farms in the affected regions.

Two questionnaire-based surveys were conducted by the Directorate of Veterinary Services (DVS) of Namibia and the Namibia Agricultural Union (NAU), mainly in the Khomas region as well as in three other regions (Otjozondjupa, Omaheke and Kunene). Farms that had abortions and those not affected were 
purposively selected for investigation. The number of questionnaires returned to DVS and NAU were 21 and 27, respectively. The DVS questionnaires were administered by veterinarians and veterinary paraprofessional staff, whereas the NAU questionnaires were completed by the farmers. However, the data was later merged. Data from 47 questionnaires were eventually analysed. The data so collected included the location of the farm (region), types of animals on the farm and their numbers, history of abortions and orchitis, feeding and grazing status, water sources, vaccination history and details of any new animals brought into the establishment. The data collected was captured onto a Microsoft Excel 2013 spreadsheet and analysed.

Laboratory samples were collected from a total of 10 farms, all of which had reported cases of abortions, stillbirths and/or orchitis. The samples were sent to the Central Veterinary Laboratory (CVL) located in Windhoek (Namibia). Some were sent to Vet Diagnostix - Veterinary Pathology Services or Onderstepoort Veterinary Institute in South Africa. These samples included sera, placentas, fetuses, swabs, organs in $10 \%$ formalin, liver samples, sheath washes as well as orchitic testes (Table 1). Laboratory tests conducted on submitted samples included immunohistochemistry, real-time polymerase chain reaction (RT-PCR), bacterial culture, histopathology, mineral analyses on liver samples and serology tests (Rose Bengal test and complement fixation test). Post-mortem examinations of orchitic testicles collected from culled animals (bulls, rams and bucks) were also done; appropriate microbiology and histopathology samples were collected and sent for laboratory analysis. A total of 18 testes ( 1 bull, 9 rams \& 8 bucks) were examined in this way. A total of 230 samples were analysed at the CVL, Vet Diagnostix - Veterinary Pathology Services (South Africa) or Onderstepoort Veterinary Institute (South Africa) or Pathcare (South Africa) (Table 1). The laboratory test results were collected, collated and then captured on Microsoft Excel and analysed.

Table 1

A summary list of numbers and types of samples collected and analysed

\begin{tabular}{|lllllll|}
\hline SAMPLES & BOVINE & OVINE & CAPRINE & EQUINE & GAME & TOTALS \\
\hline Bacterial culture & 22 & 16 & 5 & 1 & - & 44 \\
\hline Liver mineral analysis & 18 & 1 & - & - & 1 & 20 \\
\hline Histopathology & 14 & 6 & 4 & 1 & 1 & 26 \\
\hline PCR/RT-PCR & 4 & 1 & 2 & - & - & 7 \\
\hline IHC (foetus) & 1 & - & - & - & - & 1 \\
\hline Gross pathology (testes) & 1 & 9 & 8 & - & - & 18 \\
\hline Sheath washes & 10 & - & - & - & - & 10 \\
\hline Sera & 17 & 35 & 52 & - & - & 104 \\
\hline TOTALS & 87 & 66 & 71 & 2 & 2 & 230 \\
\hline
\end{tabular}


Descriptive statistics, Fisher exact test statistic and Student's t-test were used for analysing the collected data.

\section{Results}

\section{Questionnaire data}

Most of the respondents (35/47 or $74.5 \%$ ) were from the Khomas region, with the rest (12/47 or $25.5 \%)$ from Kunene, Omaheke and Otjozondjupa regions. Thus, a total of 32 out of 47 respondents $(68.1 \%)$ reported abortions on their farms. In terms of reporting of abortion, there was no significant difference between Khomas and other regions $X^{2}(1, N=47)=0.02, p=0.90$.

Table 2

summarised abortion figures on cattle farms that reported abortions

\begin{tabular}{|llllll|}
\hline Region & $\begin{array}{l}\text { No. of } \\
\text { respondents }\end{array}$ & $\begin{array}{l}\text { \# of farms } \\
\text { reporting } \\
\text { abortions }\end{array}$ & $\begin{array}{l}\text { \% of farms } \\
\text { reporting } \\
\text { abortions }\end{array}$ & $\begin{array}{l}\text { Number } \\
\text { of } \\
\text { abortions }\end{array}$ & $\begin{array}{l}\text { Average number of } \\
\text { abortions per farm }\end{array}$ \\
\hline Khomas & 35 & 24 & $68.6 \%$ & 423 & 17.7 \\
\hline Kunene & 1 & 0 & $0.0 \%$ & 0 & 0 \\
\hline Omaheke & 6 & 4 & $66.7 \%$ & 29 & 7.25 \\
\hline Otjozondjupa & 5 & 4 & $80.0 \%$ & 9 & 2.25 \\
\hline Total & 47 & 32 & $68.1 \%$ & 461 & 14.4 \\
\hline
\end{tabular}

Table 3

animal-level abortions at farms where abortions were reported

\begin{tabular}{|lllll|}
\hline Region & $\begin{array}{l}\text { Number of } \\
\text { Cattle }\end{array}$ & $\begin{array}{l}\text { Number of farms } \\
\text { reporting abortion }\end{array}$ & $\begin{array}{l}\text { Number of Abortions } \\
\text { in 2017 }\end{array}$ & $\begin{array}{l}\text { Percentage } \\
\text { aborted }\end{array}$ \\
\hline Khomas & 3850 & 16 & 509 & $13.20 \%$ \\
\hline Omaheke & 736 & 5 & 31 & $4.20 \%$ \\
\hline Otjozondjupa & 1418 & 4 & 9 & $0.60 \%$ \\
\hline Grand Total & 6004 & 25 & 549 & $9.10 \%$ \\
\hline
\end{tabular}

The data in Table 3 refers to twenty-five farms that experienced abortions and also reported the number of breeding cattle on their respective farms. Farms that did not provide the number of breeding animals were excluded from the table. There was a significant difference in the abortions at animal level among 
the three regions $X^{2}(2, N=6004)=222.16, p=.00001$. However, there was no significant difference at farm level.

Khomas region had the highest average animal-level percentage of abortions (Table 4). At the worst affected farm, $77.6 \%$ (180/232) of the breeding cows aborted, followed by others which had $47.3 \%$ $(52 / 110), 37.4 \%(40 / 70)$ and $15 \%(15 / 100)$. The second highest affected area at animal level was Omaheke region (4.2\%) which ranged from $2.5-12 \%$.

Table 4

summary of distribution of abortions at animal level comparing Khomas to other regions

\begin{tabular}{|llllll|}
\hline Region & $\begin{array}{l}\text { Number of } \\
\text { farms }\end{array}$ & $\begin{array}{l}\text { Min } \\
\text { Percentage }\end{array}$ & $\begin{array}{l}\text { Max } \\
\text { Percentage }\end{array}$ & $\begin{array}{l}\text { Average \% } \\
\text { abortion }\end{array}$ & $\begin{array}{l}\text { Standard } \\
\text { Deviation }\end{array}$ \\
\hline Khomas & 16 & $0.3 \%$ & $77.6 \%$ & $18.2 \%$ & $22.2 \%$ \\
\hline Others & 9 & $1.0 \%$ & $12.0 \%$ & $3.4 \%$ & $3.8 \%$ \\
\hline
\end{tabular}

The proportions of abortions calculated at animal level at each farm were significantly different when Khomas region was compared to the other regions. Student t-test for unequal variances-one tail (17, $\mathrm{N}=25)=2.586, \mathrm{p}=.00961$. F-Test Two-Sample for Variance $(15,8, \mathrm{~N}=25)=34.5341 \mathrm{p}=0.000013$.

Table 5

distribution of abortions by trimester as reported by the farmers.

\begin{tabular}{|llllll|}
\hline Trimester & First & Second & Third & All & Total \\
\hline FARM LEVEL & & & & & \\
\hline Number of farms & 2 & 4 & 14 & 1 & 21 \\
\hline Percentage of farms & $10 \%$ & $19 \%$ & $67 \%$ & $5 \%$ & $100 \%$ \\
\hline ANIMAL LEVEL & & & & & \\
\hline Number of breeding cattle on all farms & 154 & 1131 & 4198 & 232 & 5715 \\
\hline Number of abortions & 29 & 86 & 119 & 180 & 414 \\
\hline Animal level percentage at the farms & $19 \%$ & $8 \%$ & $3 \%$ & $78 \%$ & $7 \%$ \\
\hline ABORTIONS LEVEL & & & & & \\
\hline Percent of all abortions (414 animals) & $7 \%$ & $21 \%$ & $29 \%$ & $43 \%$ & $100 \%$ \\
\hline
\end{tabular}

A total of 21 farms reported abortions according to the trimesters in which they took place, and these were tabulated into three levels - farm, animal and abortions levels (Table 5). The rest of the farms did not indicate the trimester in which the abortions occurred. Sixty-seven per cent (14/21) of the farmers 
indicated that most of their cattle had aborted in the third trimester. However, on those farms, at animal level, the percentage of breeding animals that aborted was only $3 \%(119 / 4198)$ whereas on the one farm where animals aborted in all trimesters, $78 \%$ of the breeding cattle aborted. Of the 5715 breeding animals present on all the farms, $7 \%(414 / 5715)$ experienced abortions. When the 414 aborting animals were distributed among the stages of pregnancy $43 \%$ (178/414) aborted in the all trimesters, and the least was in the first trimester $7 \%(29 / 414)$.

Two farms in Khomas region reported abortions in the last quarter of 2016 and one of the farmers could not remember when the abortions had taken place. Only seven of the 18 farms had a recent history of abortion. (Note: data not in the table).

Table 6

distribution of abortions by parity

\begin{tabular}{|lllll|}
\hline Parity & 1st calver & 2nd calver & 3rd or more & Total \\
\hline No. of reporting farms & 6 & 4 & 2 & 12 \\
\hline No. of abortions & 98 & 82 & 20 & 200 \\
\hline Percentage & $49.5 \%$ & $41.4 \%$ & $10.0 \%$ & 100.0 \\
\hline
\end{tabular}

Twelve farms reported abortions according to parity (Table 6). Most abortions were observed in heifers $(49.5 \%$ [98/200]) followed by second calvers (41.4\% [82/200]) and lastly, third or later calvers (10\% [20/200]). The total number of animals in each parity category was not available in order to perform a valid comparison.

Orchitis was reported on only three cattle farms in the Khomas region. On one of the farms with eight affected bulls, 12 cows out of 220 aborted, whilst on the other farm with four cases of orchitis, 180 cows out of 232 aborted. The third farm, which did not specify the number of orchitis cases, experienced four abortions in cattle.

\section{Abortion and orchitis data of Farm A and Farm X}

The questionnaire survey data showed that at Farm $X$ in the Khomas region, all 44 breeding ewes and all 23 breeding does aborted. In addition, one buck and one ram had orchitis and had to be culled.

At Farm A (not included in the questionnaire survey), also in the Khomas region, 38\% (26/68) of the breeding bucks, $40 \%(38 / 96)$ of the breeding rams and $33 \%(12 / 30)$ of the breeding bulls were affected by orchitis; they were all culled as a result. Twenty-five per cent (15/60) of the breeding ewes and $24 \%$ $(12 / 50)$ of the breeding does also aborted. Fifty-eight per cent $(70 / 120)$ cows also aborted on the same farm during the same period.

\section{Pregnancy and calving percentages}


Focusing on 2017 data, the year when most abortions were reported, the pregnancy percentage between farms that reported abortion and those that did not, the one-tail t-test showed that there was no significant difference $(p=0.14)$. However there was a significant difference in calving percentages between the two categories of farms $(p=0.047)$ indicating that abortion had a negative impact on calving percentage in that year.

\section{Potential risk factors investigated}

The surveys investigated other potential risk factors and management practices that could have contributed to outbreaks on the farms involving introduction new breeding animals and contact with other animals species; non-vaccination against brucellosis; whether bull testing for campylobacteriosis and trichomoniasis was practised; co-morbidity; continuous breeding; provision of supplementary feeding; grazing and watering conditions - as summarised in Table 7. None of these factors was statistically significant ( $p>0.05$ [Fisher exact test statistic]) except for the introduction of new breeding animals. 
Table 7

summary of risk factors

\begin{tabular}{|c|c|c|c|}
\hline & Factors & $\begin{array}{l}\text { No. of farms experiencing } \\
\text { abortion }\end{array}$ & $\begin{array}{l}\text { No. of farms not } \\
\text { experiencing abortion }\end{array}$ \\
\hline \multirow[t]{2}{*}{1} & New breeding stock introduced & 14 & 7 \\
\hline & No new breeding stock Introduced & 3 & 2 \\
\hline \multirow[t]{2}{*}{2} & Contact with other cattle & 9 & 5 \\
\hline & No contact with other cattle & 8 & 4 \\
\hline \multirow[t]{2}{*}{3} & Contact with other animal species & 12 & 8 \\
\hline & $\begin{array}{l}\text { No contact with other animal } \\
\text { species }\end{array}$ & 19 & 6 \\
\hline \multirow[t]{2}{*}{4} & $\begin{array}{l}\text { Not vaccinated against } \\
\text { Brucellosis }\end{array}$ & 7 & 5 \\
\hline & Vaccinated against brucellosis & 25 & 12 \\
\hline \multirow[t]{2}{*}{5} & $\begin{array}{l}\text { No bull, rams \& bucks testing for } \\
\text { reproductive }\end{array}$ & 14 & 9 \\
\hline & $\begin{array}{l}\text { Bull, rams \& bucks testing for } \\
\text { reproductive }\end{array}$ & 17 & 8 \\
\hline \multirow[t]{2}{*}{6} & Co-morbidity + & 7 & 5 \\
\hline & Co-morbidity - & 10 & 5 \\
\hline \multirow[t]{2}{*}{7} & $\begin{array}{l}\text { Continuous breeding throughout } \\
\text { the year }\end{array}$ & 17 & 7 \\
\hline & Defined breeding season & 14 & 9 \\
\hline \multirow[t]{2}{*}{8} & No Supplementation & 11 & 4 \\
\hline & Supplementation & 36 & 20 \\
\hline \multirow[t]{2}{*}{9} & Poor grazing 2015 & 9 & 4 \\
\hline & Good grazing 2015 & 8 & 6 \\
\hline \multirow[t]{2}{*}{10} & Poor grazing 2016 & 11 & 5 \\
\hline & Good grazing 2016 & 6 & 5 \\
\hline \multirow[t]{2}{*}{11} & Water not tested & 4 & 5 \\
\hline & Water tested & 13 & 5 \\
\hline \multirow[t]{2}{*}{12} & Water abnormality detected & 1 & 0 \\
\hline & No water abnormality detected & 9 & 2 \\
\hline
\end{tabular}




\begin{tabular}{|clll|}
\hline Factors & $\begin{array}{l}\text { No. of farms experiencing } \\
\text { abortion }\end{array}$ & $\begin{array}{l}\text { No. of farms not } \\
\text { experiencing abortion }\end{array}$ \\
\hline 12 & Dam water present & 11 & 3 \\
\hline 14 & No dam water present & 6 & 7 \\
\hline 15 & Prface water present & 3 & 1 \\
\hline & No surface water present & 14 & 9 \\
\hline 16 & Presence of game on farm & 7 & 2 \\
\hline & Absence of poisonous plants & 2 & 5 \\
\hline
\end{tabular}

\section{Gross pathology}

The bulls, rams and bucks that had orchitis either had bilateral or unilateral hard and/or doughy swollen testes (Figure $1 \& 2$ ). The gross lesions included severe enlargement of the scrotal contents (Figures 1, 2 \& 7), fibrous adhesions between testicular tunics (Figures 3, 4, 8, 12, 13 \& 14) multiple testicular and epididymal abscesses with purulent exudate (Figures $8 \& 13$ ) and foci of fibrosis and calcification (Figures $3 \& 10$ ). Some of the affected testes appeared necrotic and edematous (Figures 5, 6, 9 \& 10). Necrosis of the testicular parenchyma with caseous and hemorrhagic exudate, some epididymis revealed multifocal spermatic granulomas affecting the normal tubular architecture (Figure 11). Some of the testes showed fibrosis of the tunica vaginalis (Figures $3,4,5,8,9,10,11,12,13 \& 14$ ). Multiple hemorrhagic foci on the cut surface were seen in some of the testicular samples, while peri-testicular ecchymotic haemorrhages around the tunica vaginalis was also observed (Figures 5, 6 \& 14).

\section{Histopathology}

Histopathological findings of various tissues examined in the lab are summarised in Table 8. Testicular samples were diagnosed with chronic orchitis, testicular degeneration as well as chronic epididymitis. Abnormalities observed on histopathology included abnormal architecture of the testicular structures, large foci of necrotic testicular tissue with mineralisation, moderate to severe presence of fibrous connective tissue, prominent interstitial mononuclear inflammatory cell infiltration with a few multinucleated inflammatory cells. Some testicular samples showed subacute testicular degeneration with seminiferous tubules containing mainly desquamated germinal epithelial cells and very few spermatozoa as well as mineralisation. 
Table 8

summary of histopathological diagnoses of all samples examined

\begin{tabular}{|lllllll|}
\hline Histopathological diagnosis & Bovine & Ovine & Caprine & Equine & Game & Total \\
\hline Chronic sclerosing endometritis & - & - & - & - & 1 & 1 \\
\hline Necrotising placentitis & 2 & - & - & - & - & 2 \\
\hline Meconium aspiration & 2 & - & - & - & - & 2 \\
\hline Funisitis & - & - & - & 1 & - & 1 \\
\hline Hyperplastic goitre & 1 & - & - & - & - & 1 \\
\hline Bacterial abortion & 4 & - & - & - & - & 4 \\
\hline Non-infectious abortion & - & 1 & - & - & - & 1 \\
\hline Primary infectious abortion & 1 & - & - & - & - & 1 \\
\hline Foetal cardiomyopathy & 1 & - & - & - & - & 1 \\
\hline Thymic atrophy & 1 & - & - & - & - & 1 \\
\hline Chronic epididymitis & 1 & - & - & - & - & 1 \\
\hline Chronic orchitis \& testicular degeneration & 1 & 5 & 4 & - & - & 10 \\
\hline Total & 14 & 6 & 4 & 1 & 1 & 26 \\
\hline
\end{tabular}

Diagnoses for other samples mainly included, among others, necrotising placentitis, meconium aspiration and bacterial abortion. Funisitis was also diagnosed in one equine fetus.

\section{Bacterial culture}

As shown in Tables 9 \& 10, a total of 21 different bacterial species were isolated from the 44 microbiological samples (Table 1) that were submitted to the laboratory. These samples included placentas, fetal organs and swabs collected from orchitic testes. The bacterial isolates in abortion cases (Table 9) were mostly Enterococcus spp. 63.3\% (19/30), Enterobacter spp. 10\% (3/30) and Streptococcus spp. $10 \%(3 / 30)$. The rest were at $3.3 \%(1 / 30)$ each and included Trueperella pyogenes, Stenotrophomonas maltophilia, Staphylococcus epidermidis, Providencia rettgeri and Acinetobacter iwoffii. 
Table 9

summary of bacterial culture results for abortion cases

\begin{tabular}{|llllll|}
\hline Bacteria isolated & Bovine & Ovine & Caprine & Equine & Totals \\
\hline Enterococcus casseliflavus & 3 & 0 & 0 & 0 & 3 \\
\hline Enterococcus Mundtii & 8 & 1 & 0 & 0 & 9 \\
\hline Enterecoccus sulfureus & 1 & 0 & 0 & 0 & 1 \\
\hline Enterococcus gallinarum & 3 & 0 & 0 & 0 & 3 \\
\hline Enterococcus faecalis & 1 & 0 & 0 & 0 & 1 \\
\hline Enterococcus faecium & 2 & 0 & 0 & 0 & 2 \\
\hline Enterobacter spp. & 2 & 0 & 0 & 1 & 3 \\
\hline Streptococcus suis & 1 & 0 & 0 & 0 & 1 \\
\hline Stenotrophomonas maltophilia & 1 & 0 & 0 & 0 & 1 \\
\hline Staphylococcus epidermidis & 1 & 0 & 0 & 0 & 1 \\
\hline Trueperella pyogenes & 1 & 0 & 0 & 0 & 1 \\
\hline Providencia rettgeri & 1 & 0 & 0 & 0 & 1 \\
\hline Streptococcus agalactae & 1 & 0 & 0 & 0 & 1 \\
\hline Acinetobacter iwoffii & 1 & 0 & 0 & 0 & 1 \\
\hline Beta and Alpha Streptococcus Group D & 0 & 0 & 1 & 0 & 1 \\
\hline Total & 27 & 1 & 1 & 1 & 30 \\
\hline
\end{tabular}

Eleven different species of bacteria were isolated from cases of epididymo-orchitis in bulls, rams and bucks (Table 10). The main genera of pathogens that were cultured included Streptococcus spp. (47.4\% [9/19]), Brucella spp. (10.5\% [2/19]), Enterococcus spp. (21.1\% [4/19]) and E. coli (5.3\% [1/19]). Enterococcus spp. were isolated from both cattle and goats; Streptococcus spp. were cultured from all three species (cattle, sheep \& goats), but Brucella spp. and E. coli were both isolated from bucks. The rest of the isolates included Staphylococcus pseudintermedius (bull), Sphingomonas paucimobilis (ram) and Pantoea spp. (ram), which were isolated once each (5.3\%) across the two species of livestock. 
Table 10

summary of bacterial culture results for epididymo-orchitis cases

\begin{tabular}{|lllll|}
\hline Bacteria isolated & Bovine & Ovine & Caprine & Totals \\
\hline Enterococcus casseliflavus & 1 & 0 & 0 & 1 \\
\hline Enterococcus gallinarum & 1 & 0 & 0 & 1 \\
\hline Enterococcus faecium & 1 & 0 & 0 & 1 \\
\hline Enterococcus spp. & 0 & 0 & 1 & 1 \\
\hline E. coli & 0 & 0 & 1 & 1 \\
\hline Staphylococcus pseudintermedius & 1 & 0 & 0 & 1 \\
\hline Sphingomonas paucimobilis & 0 & 1 & 0 & 1 \\
\hline Pantoea spp & 0 & 1 & 0 & 1 \\
\hline Streptococcus thoraltensis & 0 & 3 & 0 & 3 \\
\hline Streptococcus spp. & 1 & 3 & 2 & 6 \\
\hline Brucella spp. & 0 & 0 & 2 & 2 \\
\hline Total & 5 & 8 & 6 & 19 \\
\hline
\end{tabular}

\section{Polymerase chain reaction (PCR)}

A total of five aborted foetuses and two placentas from two farms were tested for the following pathogens using either PCR or real-time-PCR with negative results: Brucella spp., Coxiella burnetti, Chlamydia spp, Listeria monocytogenes, Salmonella spp., Campylobacter fetus spp., Leptospira pathogenic strains, bovine viral diarrhoea virus, Rift Valley fever virus, Anaplasma phagocytophilum, bovine herpes virus 4 . Sheath scrapping samples from 10 bulls were also tested for Campylobacter fetus spp and Trichomonas foetus spp., with negative results.

\section{Mineral analysis}

A total of 20 liver samples ( 18 bovine, 1 ovine \& 1 oryx [Oryx gazelle]) from the 10 farms were each tested for levels of copper, zinc, manganese, selenium and iron (Table 11). For the bovine samples, $28 \%(5 / 18)$, $33 \%(6 / 18), 83 \%(15 / 18), 33 \%(6 / 18)$ and (17\%) 3/18 were low in copper, zinc, manganese, selenium and iron, respectively; another $33 \%(6 / 18)$ were high in iron. 
Table 11

Summary of mineral analysis results of 20 liver samples from 20 farms

\begin{tabular}{|c|c|c|c|c|c|}
\hline Mineral & Level & Bovine & Ovine & Oryx & Totals \\
\hline & Low & 5 & - & 1 & 6 \\
\hline \multirow[t]{3}{*}{ Copper } & Normal & 12 & 1 & - & 13 \\
\hline & High & 1 & - & - & 1 \\
\hline & Low & 6 & 1 & 1 & 8 \\
\hline \multirow[t]{3}{*}{ Zinc } & Normal & 3 & - & - & 3 \\
\hline & High & 9 & - & - & 9 \\
\hline & Low & 15 & 1 & 1 & 17 \\
\hline \multirow[t]{3}{*}{ Manganese } & Normal & 3 & - & - & 3 \\
\hline & High & - & - & - & 0 \\
\hline & Low & 6 & - & - & 6 \\
\hline \multirow[t]{3}{*}{ Selenium } & Normal & 12 & 1 & 1 & 14 \\
\hline & High & - & - & - & 0 \\
\hline & Low & 3 & - & - & 3 \\
\hline \multirow[t]{2}{*}{ Iron } & Normal & 9 & - & - & 9 \\
\hline & High & 6 & 1 & 1 & 8 \\
\hline Totals & & 90 & 5 & 5 & 100 \\
\hline
\end{tabular}

The one ovine liver sample was low in zinc and manganese, but high in iron. The oryx (Oryx gazella) liver sample was low in copper, zinc and manganese but high in iron.

\section{Serology}

Table 12 gives a summary of the serology test results of 104 samples collected from one of the farms which was severely affected by abortions and epididymo-orchitis in cattle, sheep and goats. 
Table 12

Serology test results from one of the farms severely affected by the outbreak of abortions and epididymoorchitis .

\begin{tabular}{|c|c|c|c|c|c|c|}
\hline Species & $\begin{array}{l}\text { No. of } \\
\text { samples }\end{array}$ & $\begin{array}{l}\text { Brucella } \\
\text { abortus }\end{array}$ & $\begin{array}{l}\text { Brucella } \\
\text { mellitensis }\end{array}$ & $\begin{array}{l}\text { Brucella } \\
\text { ovis }\end{array}$ & $\begin{array}{l}\text { Chlamydia } \\
\text { abortus }\end{array}$ & $\begin{array}{l}\text { Coxiella } \\
\text { burnetti }\end{array}$ \\
\hline Bovine & 17 & 0 & NT & NT & NT & NT \\
\hline Caprine & 52 & NT & 12 & 0 & 0 & NT \\
\hline Ovine & 35 & NT & 1 & 1 & NT & 1 \\
\hline Totals & 104 & 0 & 13 & 1 & 0 & 1 \\
\hline \multicolumn{7}{|c|}{ NT stands for 'not tested'. } \\
\hline \multicolumn{7}{|c|}{$\begin{array}{l}\text { The } 17 \text { bovine sera were only tested for Brucella abortus using the Rose Bengal test (RBT) with } \\
\text { negative results. A total of } 12 / 52(23 \%) \text { caprine sera were positive for Brucella melitensis on both the } \\
\text { RBT and compliment fixation test (CFT), but were negative for Brucella ovis. An ELISA test was also } \\
\text { used to test the } 52 \text { caprine samples for Chlamydophila (Chlamydia) abortus and were all negative. } \\
\text { The } 35 \text { ovine sera were tested for } B \text { melitensis (RBT), B ovis (RBT) and Coxiella burnetti (ELISA); there } \\
\text { was one positive case in each. }\end{array}$} \\
\hline
\end{tabular}

\section{Other tests}

Samples of one cow and its foetus' organs were tested for Coxiella burnetti and Chlamydia abortus using immunohistochemistry with negative results. Tissues from one aborted fetus were also subjected to both the Modified Ziehl-Neelsen staining and culture for Mycobacterium spp. with negative results.

\section{Discussion}

According to Bagley (1999) and Tulu et al., (2018), abortion levels of up to $2 \%$ in cattle are generally regarded as normal, but figures upwards of $3-5 \%$ warrant investigation and intervention, in order to curtail further losses. Some studies have determined average abortion rates ranging from $4.55 \%$ in sheep to 5.61\%-11.86\% cattle (Abdelhadi et al. 2015; Dechicha et al. 2020). There is therefore no question that abortion figures of up to $77.6 \%$ at animal level, which are reported in this study, were very high and therefore constituted an outbreak that waranted further investigation.

A definitive diagnosis of the cause of abortion often presents a challenge because of the many infectious and non-infectious causes which are often responsible (Kumar et al. 2015; Tulu et al. 2018). Abortion also often follows an initial infection that may have occurred several weeks or months prior. Therefore, the causal agent is often undetectable when the abortion occurs (Tulu et al. 2018). The high cost of laboratory work to aid in diagnosing bovine abortion also compounds the problem (Tulu et al. 2018). Some investigations on causes of abortions have found that a significant proportion are due to unknown causes with some authors determining figures ranging from 47-67\% (Macías-Rioseco et al. 2020; WolfJäckel et al. 2020) in cattle, and $42 \%$ in sheep and $56 \%$ in goats (van den Brom et al. 2012). An abortion investigation in dairy cattle in Uruguay determined the aetiology in only 53\% (54/102) of cases. About 51 
of these cases were caused by infectious agents, with the following breakdown: Neospora caninum (29\%), Coxiella burnetii (6\%), Campylobacter fetus subsp. venerealis (2\%) and the rest were Bovine Parainfluenza-3 virus, Bovine Viral Diarrhea virus (BVDV), Salmonella enterica serovar Newport, Leptospira interrogans, including opportunistic bacteria Escherichia coli, Streptococcus spp., Staphylococcus spp., Mannheimia spp., Trueperella pyogenes, and Providencia stuartii, (Macías-Rioseco et al. 2020). One study demonstrated that there was serological evidence of mixed infections in cattle among abortifacient agents, raising the potential for their synergism (Okumu et al. 2019). These studies point the notion of multiplicity of causes of livestock abortions as was found in the current study.

One study showed that in up to $38 \%$ of bovine abortions, inflammatory changes were found in the placenta and fetal organs without specific aetiology being identified (Wolf-Jäckel et al. 2020). The figure was between $4 \%$ and 10\% in goats and 11-12\% in sheep (Van Den Brom et al. 2012; Van Engelen et al. 2014). The reasons for the low success rate of a definitive diagnosis of the causes of abortion lies in the fact that, quite often, diagnostic procedures may be performed well after the inciting cause has disappeared from the body of the host (Kumar et al. 2015). In addition, pathognomonic gross lesions are uncommon, and in many cases they could have been obscured by autolysis (Kumar et al. 2015). Furthermore, toxic and genetic factors are not discernible in specimens available for examination, and many causes of abortion are unknown, or at present, there are no proper diagnostic procedures for their identification (Kumar et al. 2015).

In one study conducted in Algeria, 37.3\% (32/59) of the farms surveyed had experienced abortions during the previous five years, although animal-level abortion rates were not indicated (Ghalmi et al. 2009). Our results indicate that $68.1 \%$ of surveyed farms experienced abortions. This could be due to the outbreak of abortions experienced at the time of the survey.

Twenty-three percent (12/52) of the caprine sera tested at one of the affected farms were positive for $B$. melitensis. This pathogen is a known cause of abortions in both sheep and goats (Das et al. 2008; Ndazigaruye et al. 2018). B. melitensis is an important cause, not only of abortions but also of orchitis and epididymitis in sheep and goats; it can also be an important cause of abortion in cattle in mixed farming practices. In a study investigating the causes of abortion in cows that were mixed and fed together with sheep and/or goats, PCR of $34(28 \%)$ specimens out of 120 abortion samples including fetuses and milk tested positive for B. melitensis biovar 3 (Deng et al. 2020). This was the first study to demonstrate $B$. melitensis as the main etiological agent for cows mixed with sheep and/or goats. In the areas covered in the current study, mixed farming practices involving cattle and small ruminants (sheep \& goats) is the norm rather than the exception. This might explain the abortions observed in both cattle and small ruminants in some farms.

The diagnosis of Brucella spp., as a cause of abortion in Africa has been through bacteriologic, serologic or molecular techniques and Brucella abortus biovar 3 is more associated with abortions in cattle (Ntirandekura et al. 2018). In a study of causes of abortion and risk factors associated with abortion, $B$. abortus accounted for $76,8 \%$ and $84,1 \%$ of abortions in cattle and sheep, respectively, while Mycoplasma 
accounted for $15,5 \%$ and $17,6 \%$ in cattle and sheep, respectively (Deng et al. 2020). Abortion-related risk factors included mixed farming, contact with other flocks, sheep brucellosis positivity and Mycoplasma positivity on serology (Deng et al. 2020; Ndazigaruye et al. 2018).

Di Blasio and coworkers isolated several of what they referred to as neglected opportunistic infections as causes of abortion, namely, Escherichia coli, Acinetobacter /woffii, Staphylococcus spp, Streptococcus spp, Streptococcus uberis, Streptococcus suis, Trueperella pyogenes, Mannheimia haemolytica, bacillus cereus and Norcardia spp which they indicated as seemingly emerging and co-placing the major infectious players in bovine and caprine reproductive failure (Di Blasio et al. 2019).

In the current study, Trueperella pyogenes was isolated only once from a cow abortion case (Table 9). T. pyogenes is a normal inhabitant of domestic animals' respiratory, urogenital and gastrointestinal tracts, and it, therefore, causes opportunistic infections (Di Blasio et al. 2019; Macías-Rioseco et al. 2020; Ponnusamy et al. 2017). However, it is recognised as a critical etiological agent in bovine endometritis and metritis (Goldstone et al. 2014) and has also been implicated in sporadic abortions (Ponnusamy et al. 2017; Wolf-Jäckel et al. 2020). In some studies T. pyogenes was found to account for $3 \%(5 / 162)$ to $10 \%(27 / 280)$ of cases of bovine abortions which were studied (Syrjälä et al. 2007; Wolf-Jäckel et al. 2020). It is, therefore, reasonable to assume that T. pyogenes was the cause of abortion in this particular case.

A total of $63.3 \%(19 / 30)$ of bacterial culture results yielded various species of Enterococcus as the abortive agents, predominantly E. mundtii $26.7 \%$ (8/30), E. casseliflavus and E. gallinarum each at $10 \%$ (3/30). In an earlier study on livestock abortion outbreak in Namibia from 1991 to 1992, E. casseliflavus was isolated in 33\% (30/91) of the culture samples (Basson, unpublished data). In another study of the causes of abortions in small ruminants $E$. casseliflavus was identified as an abortive agent, among other infectious causes (Schnydrig et al. 2017). In yet another study, Enterococcus species were also isolated in mastitic cow milk as well as from the genital tracts of aborted women (Hamzah and Kadim 2018). It is therefore possible that Enterococcus spp. could have been responsible for at least some of the abortions encountered in the current study.

Streptococcus suis was only isolated from one bovine fetus in the current study and is generally also regarded as an opportunistic infection in ruminants (Macías-Rioseco et al. 2020). There is, however, a report where it was implicated as the cause in a bovine abortion case (Higgins et al. 1990). It is therefore plausible that $S$. suis was a possible cause of abortion in this case.

Streptococcus spp., Enterococcus spp., Brucella spp. and E. coli were the most significant bacteria isolated from cases of epididymo-orchitis in bulls, rams and bucks. However, Brucella spp. and E. coli were only isolated from bucks. Streptococcus spp. can cause orchitis and overt testicular abscessation in cattle (Mahmoud et al. 2020) as well as epididymitis in rams (Searson 1976). The genus Brucella has a great tropism for the genitourinary system of cattle, goats, sheep and pigs, which is caused by the high concentration of erythritol in the testicular and placentary tissues of these animals (Colmenero et al. 2007). In particular, Brucella ovis has a predilection for the genital tract of sheep where it causes 
epididymitis and, rarely, abortions (Ridler and West 2011). Brucella abortus, Mycobacterium tuberculosis, Truperella pyogenes, Histophilus somni, Bovine Herpes Virus 1 (IBR/IPV) and Mycoplasma spp. have been implicated as the most common causes of orchitis in bulls (Bell 2006). Some authors contend that epididymo-orchitis is rare (approximately $1 \%$ ) in breeding bucks and that B. melitensis and Corynebacterium pseudotuberculosis are the commonest causes (Stewart and Shipley 2014). However, the findings of this study seem to contradict that notion, as evidenced by the high number of orchitis cases in bulls, rams and bucks at Farm A, ranging from 33-40\% during this outbreak.

It is therefore reasonable to assume that the Brucella spp. that were isolated in the current study were at least partially responsible for some of the cases of epididymo-orchitis that were observed in bucks in this study. Enterococcus spp., along with other bacteria like Pseudomonas spp. and Klebsiella spp., have also been implicated in causing epididymo-orchitis in man (Ryan et al. 2018), but no study has implicated this bacteria as a cause in domestic animals. However, the current study has demonstrated that Enterococcus spp. should be considered as a cause of epididymo-orchitis in bulls, rams and bucks, as well as abortions.

Non-infectious causes of abortion in cattle include chemical, physical, genetic, hormonal and iatrogenic factors (Ghalmi et al. 2009; Souza et al. 2018). One study provided nutritional causes such as starvation or energy deficiency which can result in embryonic or fetal death; imbalance of protein which can result in the lowering of uterine $\mathrm{pH}$ thereby reducing embryonic survival; iodine deficiency which can result in fetal goitre and increased neonatal death as well as abortion; manganese deficiency which results in lowered fertility; phytotoxicity associated with accumulation of nitrates in plants during dry spells which can result in abortions and congenital causes such as bovine leukocyte deficiency (Zekarias et al. 2019). In addition, Tulu and others mentioned heat stress, season, serum progesterone levels after conception, twin pregnancy, vaccination status against abortifacient diseases, communal grazing hygiene and animal management as non-infectious causes of abortion (Tulu et al. 2018).

In the current study, the number of bovine liver samples which had low levels of copper, zinc, manganese, selenium or iron ranged from (17\%) $3 / 18$ for iron to $83 \%$ (15/18) for manganese. Trace element deficiencies have also been implicated in causing abortions (Kumar et al. 2015). Minerals such as copper, cobalt, selenium, manganese, iodine, zinc and iron can influence the reproductive performance of ruminants (Kumar et al. 2015; Zekarias et al. 2019) and have been reported to be a predisposing factor for the occurrence of retention of placentas and repeat breeding in dairy cows, abortion and weak calf syndrome (Balmurugan et al. 2017; Yasothai 2014). However, the progesterone metabolite allopregnanolone has also been implicated in the pathogenesis of weak calf syndrome (Riedel et al. 2018), although other authors suggest a genetic predisposition (Zepeda-batista et al. 2018). In another study, low serum concentration levels of zinc and high serum copper levels have been associated with increased risk of fetal loss (Graham et al. 1994). Copper deficiency has also been reported to be associated with early embryonic death and resorption of the embryo, increased chances of retained placenta and necrosis of the placenta (Yasothai 2014). 
It would therefore appear from the mineral results that micronutrient imbalances were at least a contributing factor to the abortion/stillbirth and epididymo-orchitis outbreak. Copper and zinc deficiency appeared to be a common thread in all of the results, and both minerals are essential for metabolism and proper function of the immune system (Fraker and King 2004; Minatel 2000). This might explain the many species of bacteria which were isolated. It is the authors' contention that in-utero growth retardation as a result of maternal malnutrition or over-nutrition in conjunction with the immunosuppressive effects of the micronutrient imbalances were significant factors during this outbreak.

As regards the pathology in the bull, this could very well be related to the underlying copper deficiency noted. Copper deficiency has a significant negative impact on the male reproductive tract, and in addition, the immunosuppressive effects would predispose to the development of epididymitis.

Toxins from certain species of plants such as Ponderosa pine needles (Pinus ponderosa), locoweed (Oxytropis or Astragalus spp.), broomweed (Guttierrezia microcephala) as well as coumarins from rat poison, many grasses, moldy sweet clover, heat stress can also cause abortions (Kumar et al. 2015; Tibary 2021). However, none of these causes were proven or suspected to be responsible for any of the cases of abortion in the current study, although they cannot be entirely ruled out.

Swerczek and Dorton (2019) reported that Mare Reproductive Loss Syndrome (MRLS) has been known to affect horses in Kentucky for decades, causing, among other things, outbreaks of spontaneous abortions. The authors further noted that these fetal losses, with an unknown aetiology, but associated with MRLS occurred in mares and other livestock that were grazing in spring pastures affected by climatic and environmental factors like droughts, cold-stress, nitrogenous fertilisers, and herbicides; factors that cause nitrate to accumulate in these pastures. This excessive accumulation of nitrate was reported to result in the formation of toxic and pathogenic abiotic nanoparticles in the amniotic fluid and pathognomonic placental lesions consistent with the MRLS. The authors then hypothesised that this recently discovered mechanism of action for the pathogenesis of fetal losses might be a predisposing factor for a host of opportunistic diseases in livestock (Swerczek and Dorton 2019). The Kentucky scenario mirrors the circumstances of the outbreaks of abortions in Namibia in the periods 1991-1992 and 2016-2018.

The years 1991-1992 and 2015-2016 were marked by severe droughts in Namibia (Devereux and Næraa 1996; Holloway 2000; Kahiurika 2016; van Rensburg and Tortajada 2021). It is therefore possible, as reported by Swerczek and Dorton (2019), that these drought periods which preceded the major outbreaks of abortions in the country could have resulted from excessive accumulation of nitrate in the pastures, which when consumed by pregnant animals, could have caused the formation of toxic and pathogenic abiotic nanoparticles in the amniotic fluid thereby predisposing the pregnant animals to a host of opportunistic infections resulting in the outbreaks of abortions.

In summary, the study identified a multiplicity of possible etiologies of the reproductive problems that occurred in the central regions of Namibia from 2016 to 2018. Any number of combinations of the causes identified in this study, could cause the observed outbreaks. However, why these conditions occurred in these species, parts of the country and at these related time periods remains elusive. Perhaps, 
controlled focused studies of future abortions, orchitis and epididymitis in specific animal species may shed light on the temporal and spatial relationships of the reproductive problems and, hence, their etiologies.

\section{Declarations}

\section{Acknowledgement}

The authors would like to thank the Directorate of Veterinary Services in Namibia for providing the data which was used for this study. Our appreciation also goes to the Namibia Agricultural Union and the University of Namibia for their tremendous support.

Funding: Not applicable

Conflicts of interest: The authors declare no conflict of interest.

Ethics approval: Ethical approval was waived because this restrospective study only involved the use of secondary data.

Consent to participate: Informed consent was obtained from all farmers included in the study.

Consent for publication: The authors affirm that the participating farmers provided informed consent for publication of the data collected.

Availability of data and material: The datasets generated during and/or analysed during the current study are not publicly available for confidentiality reasons but are available from the corresponding author on reasonable request.

Code availability: Microsoft Office 2013

Authors' contributions: All authors contributed to the study conception and design.Material preparation, data collection and analysis were performed by Alaster Samkange, Jolandie van der Westhuizen, Anselm Siegfried Voigts, Frank Chitate, Israel Kaatura, Emmanuel H. Hikufe, Juliet Kabajani, Alec S. Bishi and Ndahafa N. Hawanga. The first draft of the manuscript was written by Alaster Samkange and all authors commented on previous versions of the manuscript. All authors read and approved the final manuscript.

\section{References}

1. Abdelhadi, F.Z., Abdelhadi, S.A., Niar, A., Benallou, B., Meliani, S., Smail, N.L., et al., 2015, 'Abortions in Cattle on the Level of Tiaret Area (Algeria)', Global Veterinaria 14, 638-645.

2. Balmurugan, B., Ramamoorthy, M., Mandal, R.S.K., Keerthana, J., Gopalakrishnan, G., Kavya, K.M., et al., 2017, 'Mineral an important nutrient for efficient reproductive health in dairy cattle', International Journal of Science, Environment and Technology 6, 694-701. 
3. Bell, G., 2006, 'Clinical: Diseases of the bovine scrotum', Livestock 11, 19-23.

4. Bishi, A.S., Khaiseb, S., Shaanika, A., Kandiwa, E., Mushonga, B., Samkange, A., et al., 2018, 'Serological evidence of coxiellosis in sheep farms of Namibia', Indian Journal of Small Ruminants 24, 168-170.

5. Di Blasio, A., Traversa, A., Giacometti, F., Chiesa, F., Piva, S., Decastelli, L., et al., 2019, 'Isolation of Arcobacter species and other neglected opportunistic agents from aborted bovine and caprine fetuses', BMC Veterinary Research 15, 257.

6. Van Den Brom, R., Lievaart-Peterson, K., Luttikholt, S., Peperkamp, K., Wouda, W. \& Vellema, P., 2012, 'Abortion in small ruminants in the Netherlands between 2006 and 2011', Tijdschrift voor Diergeneeskunde 137, 450-457.

7. Bulut, H., Sozdutmaz, I., Pesti, Z., Abayli, H., Sait, A. \& Cevik, A., 2017, 'High Prevalence of Bovine Viral Diarrhea Virus-1 in Sheep Abortion Samples with Pestivirus Infection in Turkey', Pakistan Veterinary Journal 38, 71-75.

8. Colmenero, J.D., Muñoz-Roca, N.L., Bermudez, P., Plata, A., Villalobos, A. \& Reguera, J.M., 2007, 'Clinical findings, diagnostic approach, and outcome of Brucella melitensis epididymo-orchitis', Diagnostic Microbiology and Infectious Disease 57, 367-372.

9. Dąbrowska, J., Karamon, J., Kochanowski, M., Sroka, J., Zdybel, J. \& Cencek, T., 2019, 'Tritrichomonas Foetus as a Causative Agent of Tritrichomonosis in Different Animal Hosts', Journal of Veterinary Research 63, 533, viewed 28 August 2021, from /pmc/articles/PMC6950439/.

10. Das, T., Ershaduzzaman, M., Islam, K.K., Haque, M.M., Rahman, M.M. \& Islam, K.B.M.S., 2008, 'Surveillance of Brucella melitensis and Brucella abortus from Aborted Bengal Goats in Bangladesh', Research Journal of Veterinary Sciences 1, 28-36.

11. Dechicha, A.S., Moula, N., Gharbi, I., Baazize-Ammi, D., Akloul, K. \& Guetarni, D., 2020, 'Abortions in cattle and sheep herds in Algeria, descriptive study and risk factors', Agriculture 1-2, 201-213.

12. Deng, X., Zhang, H., Shao, Z., Zhao, X., Yang, Q., Song, S., et al., 2020, 'Abortion and various associated risk factors in dairy cow and sheep in Ili, China', bioRxiv, 2020.04.20.050872, viewed 25 November 2020, from https://doi.org/10.1101/2020.04.20.050872.

13. Derdour, S.-Y., Hafsi, F., Azzag, N., Tennah, S., Laamari, A., China, B., et al., 2017, 'Prevalence of The Main Infectious Causes of Abortion in Dairy Cattle in Algeria', Journal of Veterinary Research 61, 337, viewed 28 August 2021, from Lpmc/articles/PMC5894425/.

14. Devereux, S. \& Næraa, T., 1996, 'Drought and survival in rural Namibia', Journal of Southern African Studies 22, 421-440.

15. Dun, K., 2019, 'Ovine abortion - causes and diagnosis', Livestock 24, 44-50.

16. Van Engelen, E., Luttikholt, S., Peperkamp, K., Vellema, P. \& Van Den Brom, R., 2014, 'Small ruminant abortions in The Netherlands during lambing season 2012-2013', Veterinary Record 174, 506.

17. Fraker, P.J. \& King, L.E., 2004, 'Reprogramming of the Immune System During Zinc Deficiency', Annual Review of Nutrition 24, 277-298. 
18. Gerdes, G.H., 2004, 'Rift Valley fever', Revue scientifique et technique (International Office of Epizootics) 23, 613-623.

19. Ghalmi, F., Dramchini, N. \& China, B., 2009, 'Risk factors for abortion in cattle herds in Algeria', Veterinary Record 165, 475-476.

20. Goldstone, R.J., Talbot, R., Schuberth, H.J., Sandra, O., Sheldon, I.M. \& Smitha, D.G.E., 2014, 'Draft genome sequence of Trueperella pyogenes, isolated from the infected uterus of a postpartum cow with metritis', Genome Announcements 2, 1-2.

21. Graham, T.W., Thurmond, M.C., Gershwin, M.E., Picanso, J.P., Garvey, J.S. \& Keen, C.L., 1994, 'Serum and copper concentrations in relation to spontaneous abortion in cows: implications for human fetal loss', Journal of Reproduction and Infertility 102, 253-262.

22. Grooms, D.L., 2006, 'Reproductive losses caused by bovine viral diarrhea virus and leptospirosis', Theriogenology 66, 624-628.

23. Hamzah, A.M. \& Kadim, H.K., 2018, 'Isolation and identification of Enterococcus fecalis from cow milk samples and vaginal swab from human', Journal of Entomology and Zoology Studies 6, 218222.

24. Higgins, R., Gottschalk, M., Fecteau, G., Sauvageau, R., De Guise, S. \& Du Tremblay, D., 1990, 'Isolation of Streptococcus suis from cattle', Canadian Veterinary Journal 31, 529.

25. Holloway, A., 2000, 'Drought emergency, yes...drought, no: Southern Africa 1991-93', Cambridge Review of International Affairs 14, 254-276.

26. Kahiurika, N., 2016, 'President declares drought an emergency', The Namibian, 1, viewed 10 February 2021, from https://www.namibian.com.na/152587/archive-read/President-declares-drought-anemergency.

27. Kováčová, D., Zubrický, P., Babiněáková, M. \& Trávniček, M., 2007, 'Importance of serological diagnostics in ovine epididymitis caused by brucella OVIS', Bulletin of the Veterinary Institute in Pulawy 51, 219-224.

28. Kumar, A., Kumar, S., Singh, M., Gokuldas, P.P. \& Kumar, P., 2015, 'Non-infectious causes of bubaline abortions', in G. N. Purohit (ed.) Bubaline Theriogenology, International Veterinary Information Service, Ithaca NY., from www.ivis.org.

29. Macías-Rioseco, M., Silveira, C., Fraga, M., Casaux, L., Cabrera, A., Francia, M.E., et al., 2020, 'Causes of abortion in dairy cows in Uruguay', Pesquisa Veterinaria Brasileira 40, 325-332.

30. Mahmoud, M.A.M., Megahed, G., Yousef, M.S., Abo, F., Ali, Z.F.A.Z., Zaki, R.S., et al., 2020, 'Salmonella Typhimurium Triggered Unilateral Epididymo-Orchitis and Splenomegaly in a Holstein Bull in Assiut, Egypt: A Case Report', Pathogens 9.

31. McAllister, M.M., 2020, Neosporosis in Animals, MSD Veterinary Manual, viewed 28 March 2021, from https:// www.msdvetmanual.com/generalized-conditions/neosporosis/neosporosis-in-animals? query=neospora caninum.

32. Minatel, L., 2000, 'Copper Deficiency and Immune Response in Ruminants', Nutrition Research 20, 1473-1484. 
33. Molini, U., Dondona, A.C., Hilbert, R. \& Monaco, F., 2018, 'Antibodies against Schmallenberg virus detected in cattle in the Otjozondjupa region, Namibia', Journal of the South African Veterinary Association 89, 1-2.

34. Ndazigaruye, G., Mushonga, B., Kandiwa, E., Samkange, A. \& Segwagwe, B.E., 2018, 'Prevalence and risk factors for brucellosis seropositivity in cattle in Nyagatare District, Eastern Province, Rwanda', Journal of South African Veterinary Association 89, a1625.

35. Ntirandekura, J., Matemba, L.E., Kimera, S.I., Muma, B. \& Karimuribo, E.D., 2018, 'Association of Brucellosis with Abortion Prevalence in Humans and Animals in Africa: A Review', African Journal of Reproductive Health 22, 120-136.

36. Okumu, T.A., John, N.M., Wabacha, J.K., Tsuma, V. \& Vanleeuwen, J., 2019, 'Seroprevalence of antibodies for bovine viral diarrhoea virus, Brucella abortus and Neospora caninum, and their roles in the incidence of abortion / foetal loss in dairy cattle herds in Nakuru District, Kenya', BMC Veterinary Research 15, 95.

37. Parkinson, T.J., Weston, J.F., Laven, R.A. \& Vermunt, J.J., 2019, 'Causes of embryonic and fetal loss', in T. J. Parkinson et al. (eds.) Diseases of cattle in Australasia, p. 667, Massey University Press, Auckland, New Zealand.

38. Ponnusamy, P., Ronald, B.S.M., Kumar, M.R., Chitra, M.A. \& Manickam, R., 2017, 'A rare case of bovine abortion due to Trueperella pyogenes', International Journal of Science, Environment and Technology 6, 284-287.

39. Reichel, M.P., Ayanegui-alcérreca, M.A., Gondim, L.F.P. \& Ellis, J.T., 2013, 'What is the global economic impact of Neospora caninum in cattle - The billion dollar question', International Journal for Parasitology 43, 133-142, from http://dx.doi.org/10.1016/j.jpara.2012.10.022.

40. van Rensburg, P. \& Tortajada, C., 2021, 'An Assessment of the 2015-2017 Drought in Windhoek', Frontiers in Climate 3,1-14.

41. Ridler, A.L. \& West, D.M., 2011, 'Control of Brucella ovis Infection in Sheep', Veterinary Clinics of North America - Food Animal Practice 27, 61-66, from http://dx.doi.org/10.1016/j.cvfa.2010.10.013.

42. Riedel, P., Dascanio, J., Johnson, J. \& Miller, L., 2018, 'Implications of allopregnanolone in weak calf syndrome', in American Association of Bovine Practitioners Proceedings of the Annual Conference, $p$. 332.

43. Ryan, L., Daly, P., Cullen, I. \& Doyle, M., 2018, 'Epididymo-orchitis caused by enteric organisms in men > 35 years old: beyond fluoroquinolones', European Journal of Clinical Microbiology and Infectious Diseases 37, 1001-1008.

44. Samkange, A., Katsande, T.C., Tjipura-Zaire, G. \& Crafford, J.E., 2010, 'Seroprevalence survey of Chlamydophila abortus infection in breeding goats on commercial farms in the Otavi Veterinary District, northern Namibia', Onderstepoort Journal of Veterinary Research 77, 1-5.

45. Dos Santos, F.A., De Azevedo, E.O., De Azevedo, S.S., Júnior, F.G., Mota, R.A., Kim, P. de C.P., et al., 2014, 'Isolation of Actinobacillus seminis from a goat with clinical epididymo-orchitis in Brazil', Brazilian Journal of Microbiology 45, 205-209. 
46. Saxena, N., Singh, B.B. \& Saxena, H.M., 2018, 'Brucellosis in Sheep and Goats and its Serodiagnosis and Epidemiology', International Journal of Current Microbiology and Applied Sciences 7, 18481877.

47. Schnydrig, P., Vidal, S., Brodard, I., Frey, C.F., Posthaus, H., Perreten, V., et al., 2017, 'Bacterial, fungal, parasitological and pathological analyses of abortions in small ruminants from 2012-2016', Schweizer Archiv fur Tierheilkunde 159, 647-656.

48. Searson, J.E., 1976, Ovine Epididymitis: Patholgy, Bacteriology and Serology, Wagga Wagga, Australia.

49. Sibhat, B., Ayelet, G., Gebremedhin, E.Z., Skjerve, E. \& Asmare, K., 2018, 'Seroprevalence of Schmallenberg virus in dairy cattle in Ethiopia', Acta Tropica 178, 61-67.

50. Souza, F., Carneiro, L.C., Cesar, J. \& Dos Santos, R.M., 2018, 'Non-infectious causes that increase early and mid-to-late pregnancy loss rates in a crossbreed dairy herd', Tropical Animal Health and Production 51, 759-765.

51. Staff Reporter, 2017, 'Livestock abortions reach unprecedented levels', New Era, from https://neweralive.na/posts/livestock-abortions-reach-unprecedented-levels.

52. Stewart, J.L. \& Shipley, C.F., 2014, Breeding Soundness Examination in Goats - Management and Nutrition - Veterinary Manual, MSD Veterinary Manual, viewed 7 February 2021, from https://www.msdvetmanual.com/management-and-nutrition/management-of-reproductiongoats/breeding-soundness-examination-in-goats.

53. Stewart, J.L., Vieson, M. \& Shipley, C.F., 2018, 'Corynebacterium pseudotuberculosis as a pathogen of the reproductive tract of male small ruminants: case study and review', Clinical Theriogenology 10, 107-117.

54. Swerczek, T.W. \& Dorton, A.R., 2019, 'Effects of Nitrate and Pathogenic Nanoparticles on Reproductive Losses, Congenital Hypothyroidism and Musculoskeletal Abnormalities in Mares and Other Livestock: New Hypotheses', Animal and Veterinary Sciences 7, 1-11.

55. Syrjälä, P., Anttila, M., Dillard, K., Fossi, M., Collin, K., Nylund, M., et al., 2007, 'Causes of bovine abortion, stillbirth and neonatal death in Finland 1999-2006', Acta Veterinaria Scandinavica 49, S3.

56. Tibary, A., 2021, Overview of Abortion in Large Animals, Merck Veterinary Manual, viewed 25 October 2021, from https://www.msdvetmanual.com/reproductive-system/abortion-in-largeanimals/overview-of-abortion-in-large-animals.

57. Tulu, D., Deresa, B., Begna, F. \& Gojam, A., 2018, 'Review of common causes of abortion in dairy cattle in Ethiopia', Journal of Veterinary Medicine and Animal Health 10, 1-13.

58. Tulu, D., Gojam, A. \& Deresa, B., 2020, 'Serological investigation of brucellosis and its association with abortion in sheep and goats in selected districts of Jimma zone, southwestern Ethiopia', Ethiopian Veterinary Journalan 24, 15-33.

59. Umer Chhalgari, M., Abba, Y., Firdaus Jesse, F.A., Monther Mohammed Saleh, W., Umer, M., Sciences, M., et al., 2017, 'Caseous lymphadenitis in small ruminants: An overview on reproductive implications Pathogenesis of Ruminant diseases View project characterization of Grouper Iridovirus GIV isolated 
from Grouper in Peninsular Malaysia View project International Journal of Veterinary Sciences and Animal Husbandry 2017, 2(2): 23-31 Caseous lymphadenitis in small ruminants: An overview on reproductive implications', viewed 28 August 2021, from www.veterinarypaper.com.

60. Vermunt, J.J., House, J.K. \& Malmo, J., 2019, 'Infectious bovine rhinotracheitis and infectious pustular vulvovaginitis', in T. J. Parkinson et al. (eds.) Diseases of cattle in Australasia, pp. 288-289, Massey University Press, Auckland, New Zealand.

61. Wolf-Jäckel, G.A., Hansen, M.S., Larsen, G., Holm, E., Agerholm, J.S. \& Jensen, T.K., 2020, 'Diagnostic studies of abortion in Danish cattle 2015-2017', Acta Veterinaria Scandinavica 62, from https://doi.org/10.1186/s13028-019-0499-4.

62. Yasothai, R., 2014, 'Importance of minerals on reproduction in dairy cattle', International Journal of Science, Environment and Technology 3, 2051-2057.

63. Zekarias, T., Demissie, E., Ahmed, W.A., Dema, T. \& Amsalu, A., 2019, 'Non-Infectious Causes of Infertility in Dairy Cows: A Review', Journal of Reproduction and Infertility 10, 51-57.

64. Zepeda-batista, J.L., Parra-bracamonte, G.M., Núñez-domínguez, R., Ramírez-valverde, R. \& Ruízflores, A., 2018, 'Screening genetic diseases prevalence in Braunvieh cattle', Tropical Animal Health and Production.

\section{Figures}

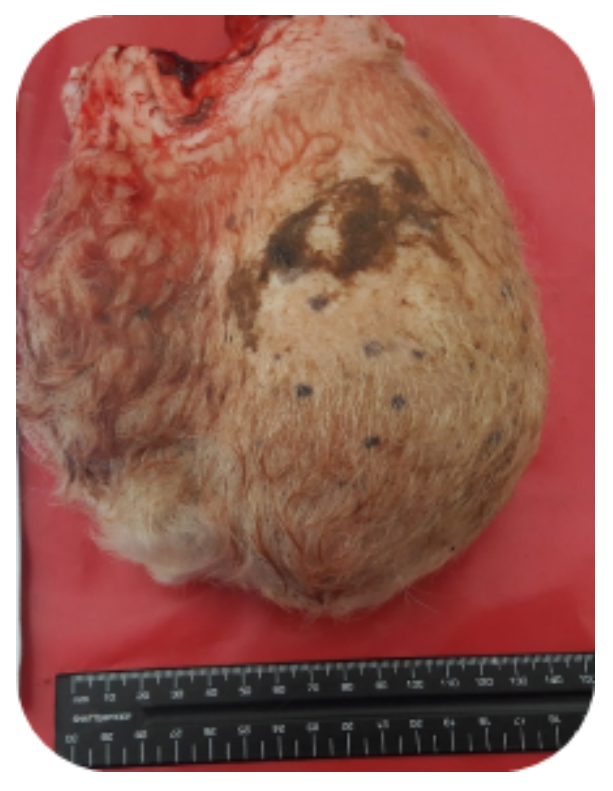

\section{Figure 1}

A swollen globular shaped right testicle of a ram with orchitis. 


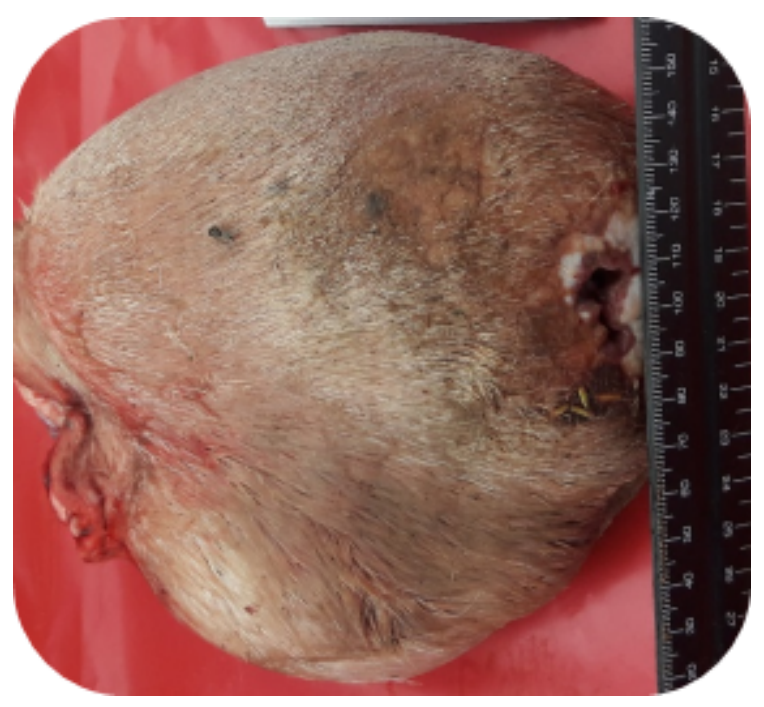

Figure 2

A fistulous tract through the scrotum of a ram with severe epididymitis and orchitis.

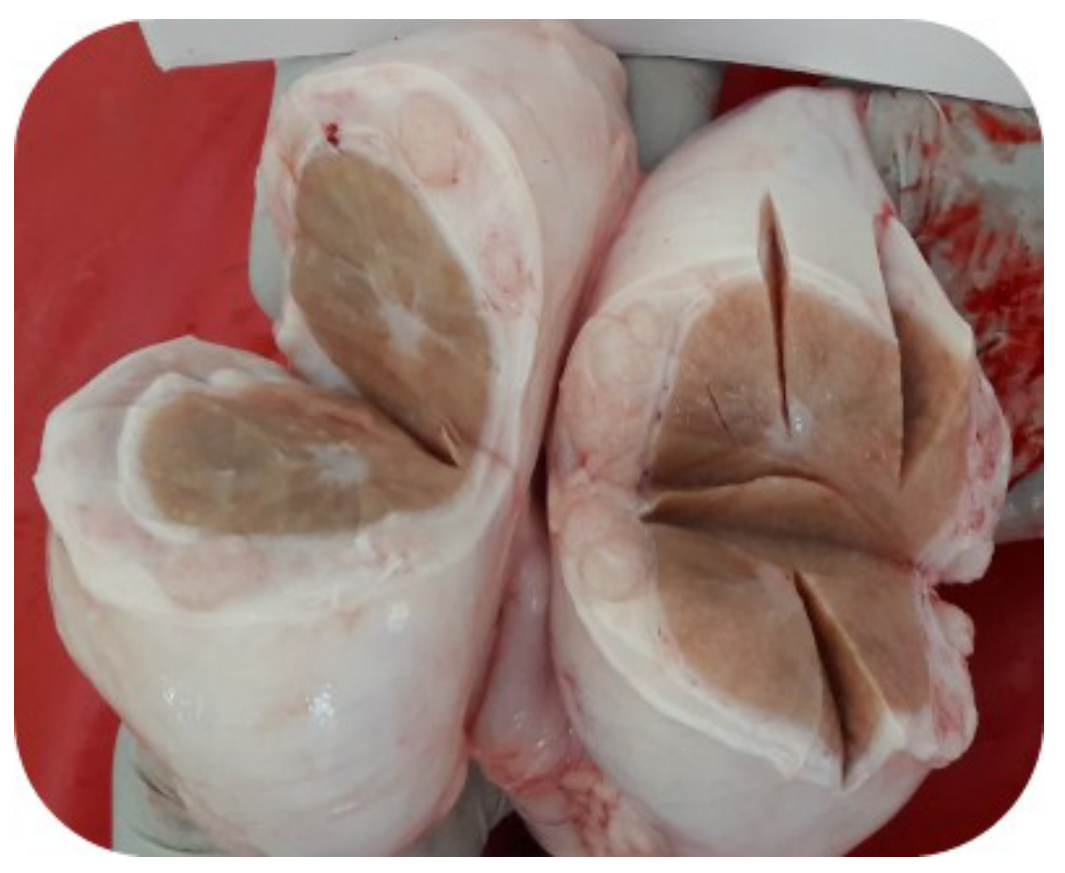

Figure 3

Fibrous hypertrophy of tunica vaginalis and fibrotic testicular parenchyma. 


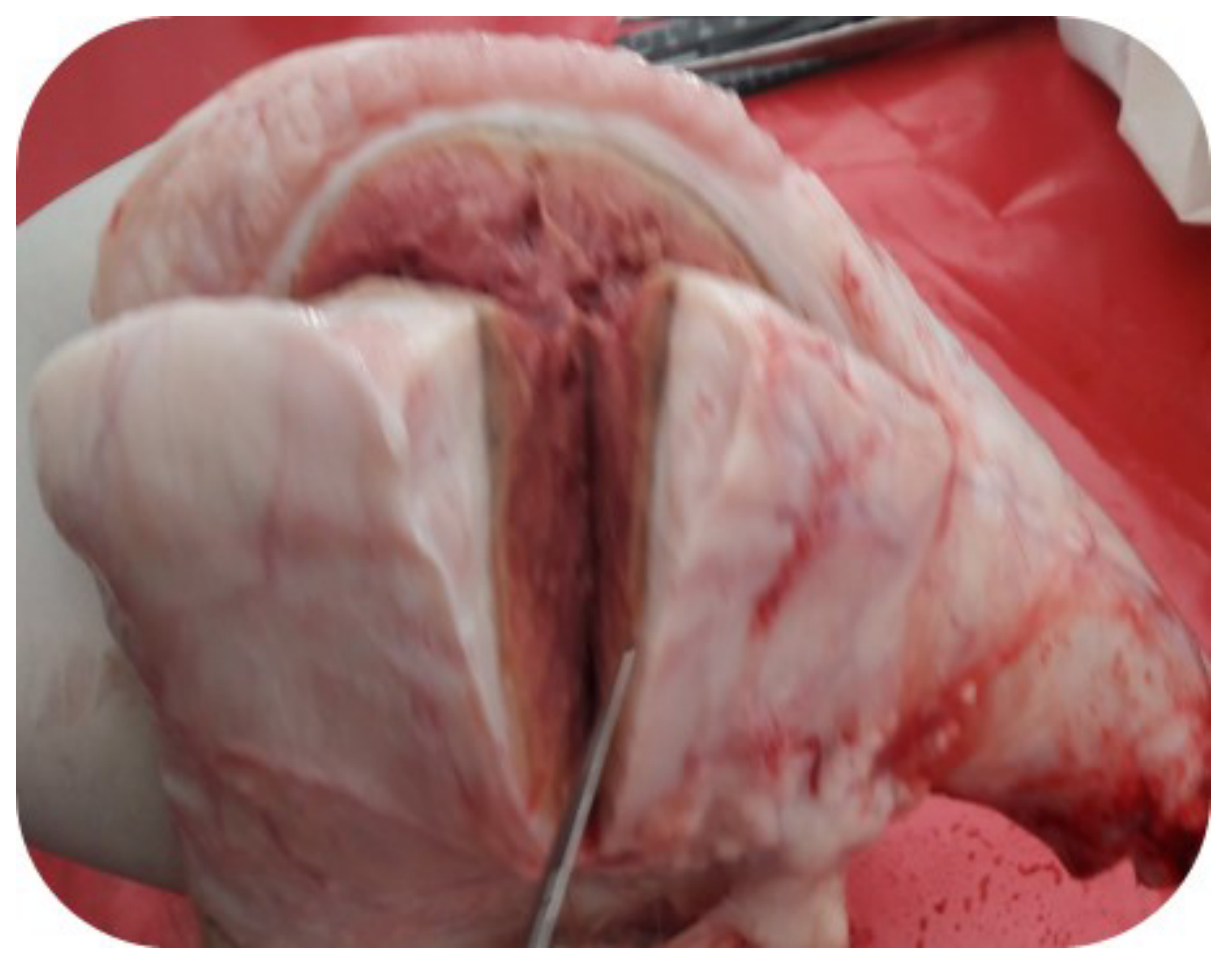

Figure 4

Bulges on cut surface, testicular parenchyma appears uniformly necrotic and reddish in color. Hyperplastic and fibrotic tunica vaginalis.

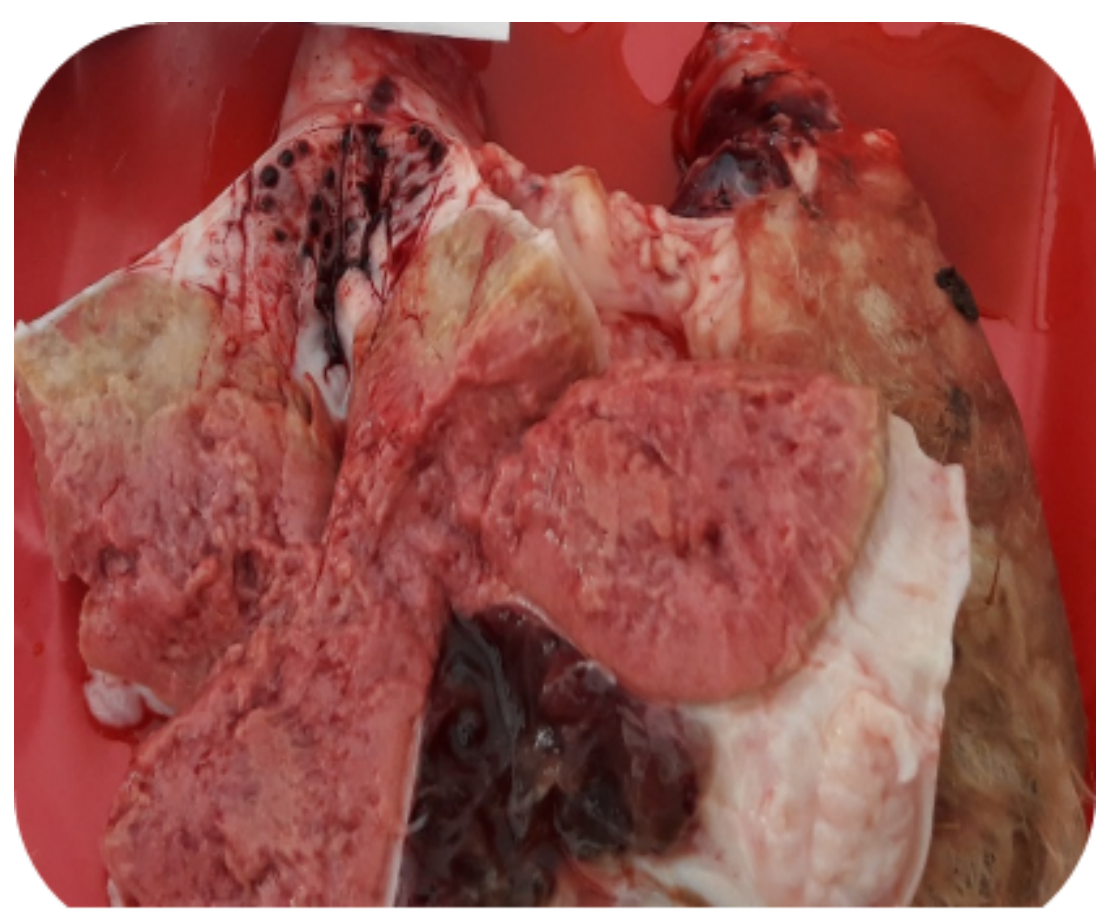

Figure 5

A necrotic testicular parenchyma with ecchymotic hemorrhages of the head of the epididymis. A necrotic and edematous tail of the epididymis with multiple fluid filled cysts 


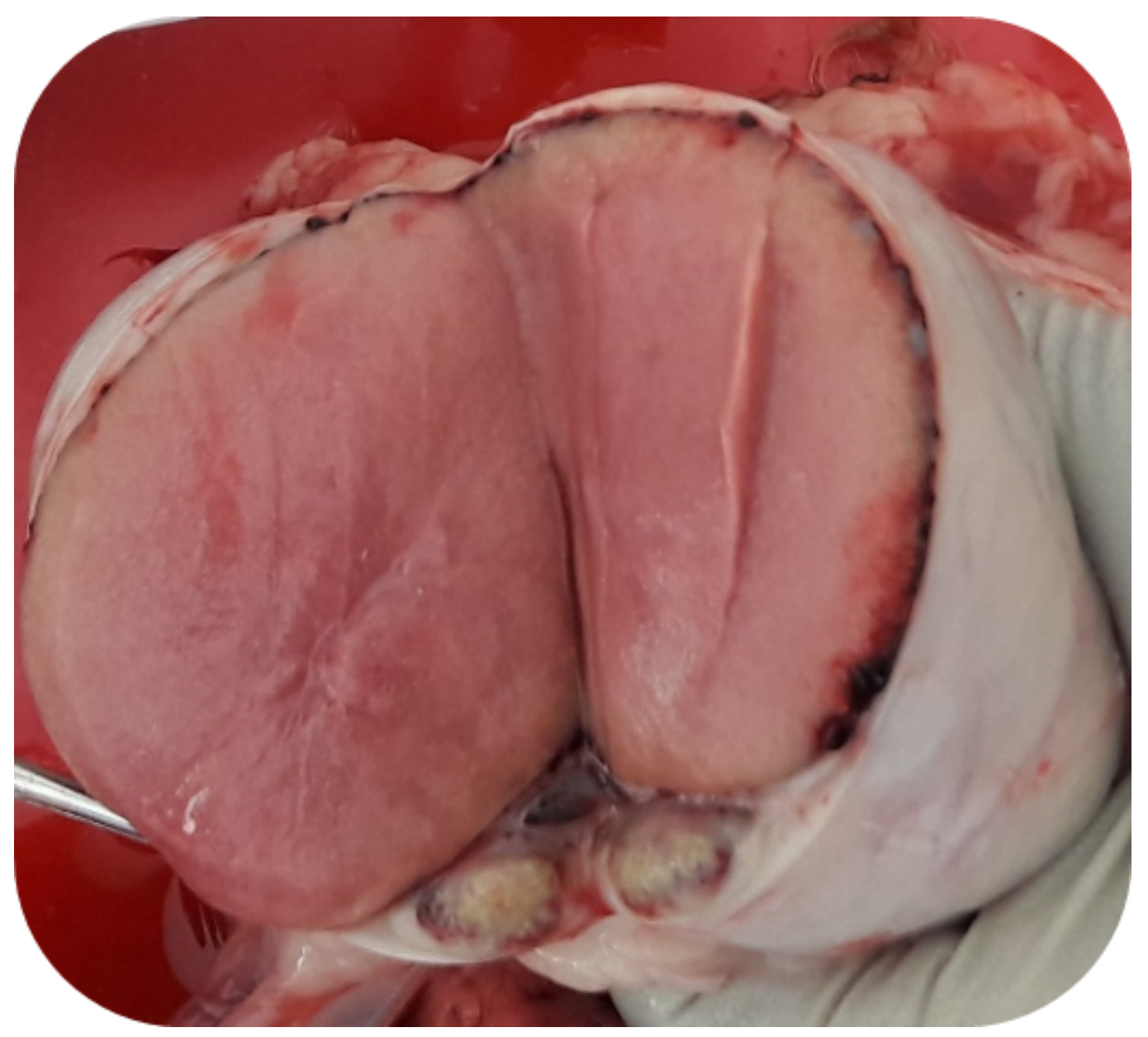

Figure 6

Testicular necrosis and peri-testicular ecchymotic hemorrhages around the tunica vaginalis.

\section{Figure 7}

Multiple hemorrhagic foci on the cut surface of the testicle, the head of the epididymis appears hemorrhagic. 


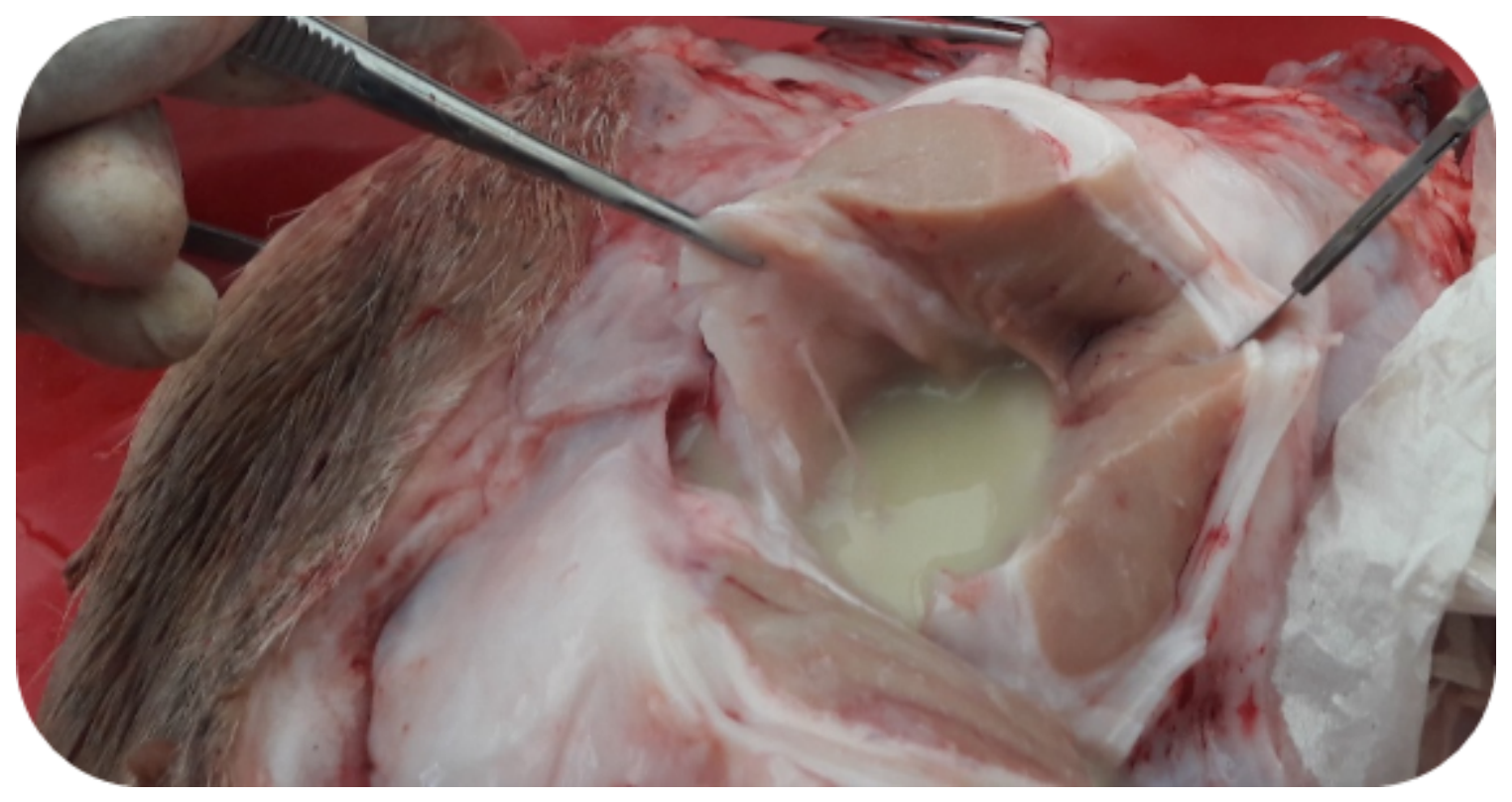

Figure 8

A cavity containing purulent exudate. The tunica vaginalis appears fibrotic.

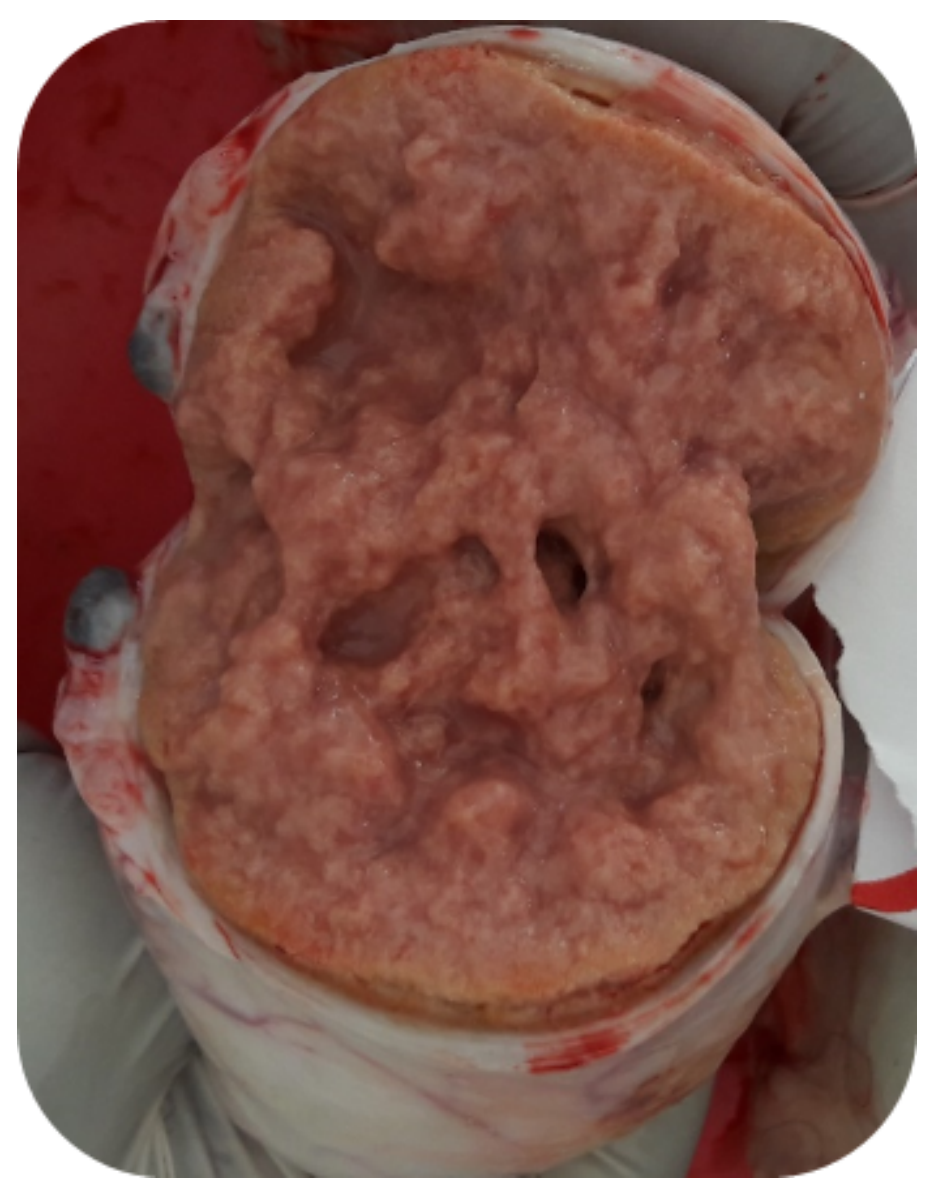

Figure 9

Severe and diffuse necrotic testicular parenchyma in a ram with orchitis. 


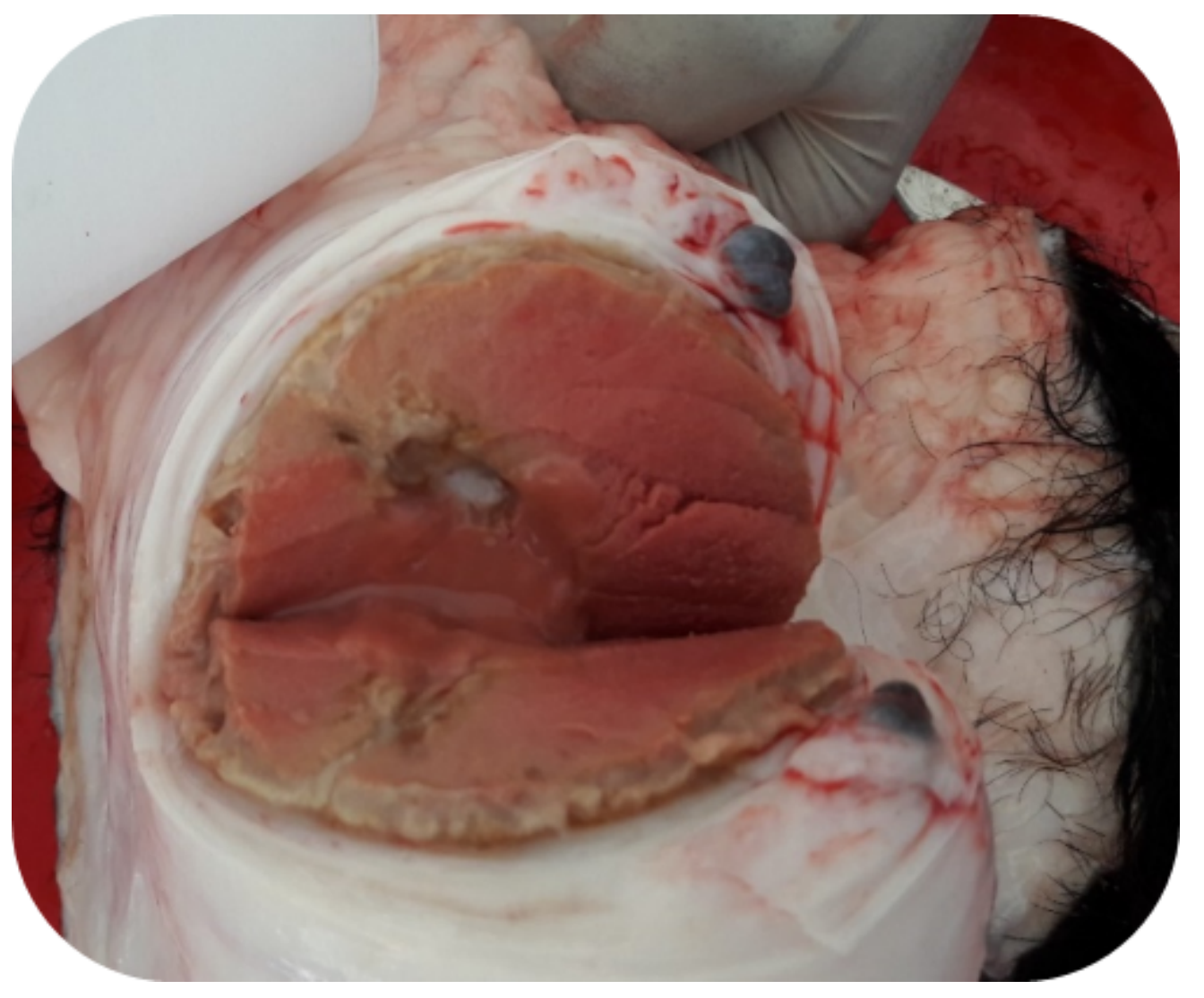

Figure 10

A focal testicular cavity filled with suppurative exudate. The testicular parenchyma appear fibrotic. 


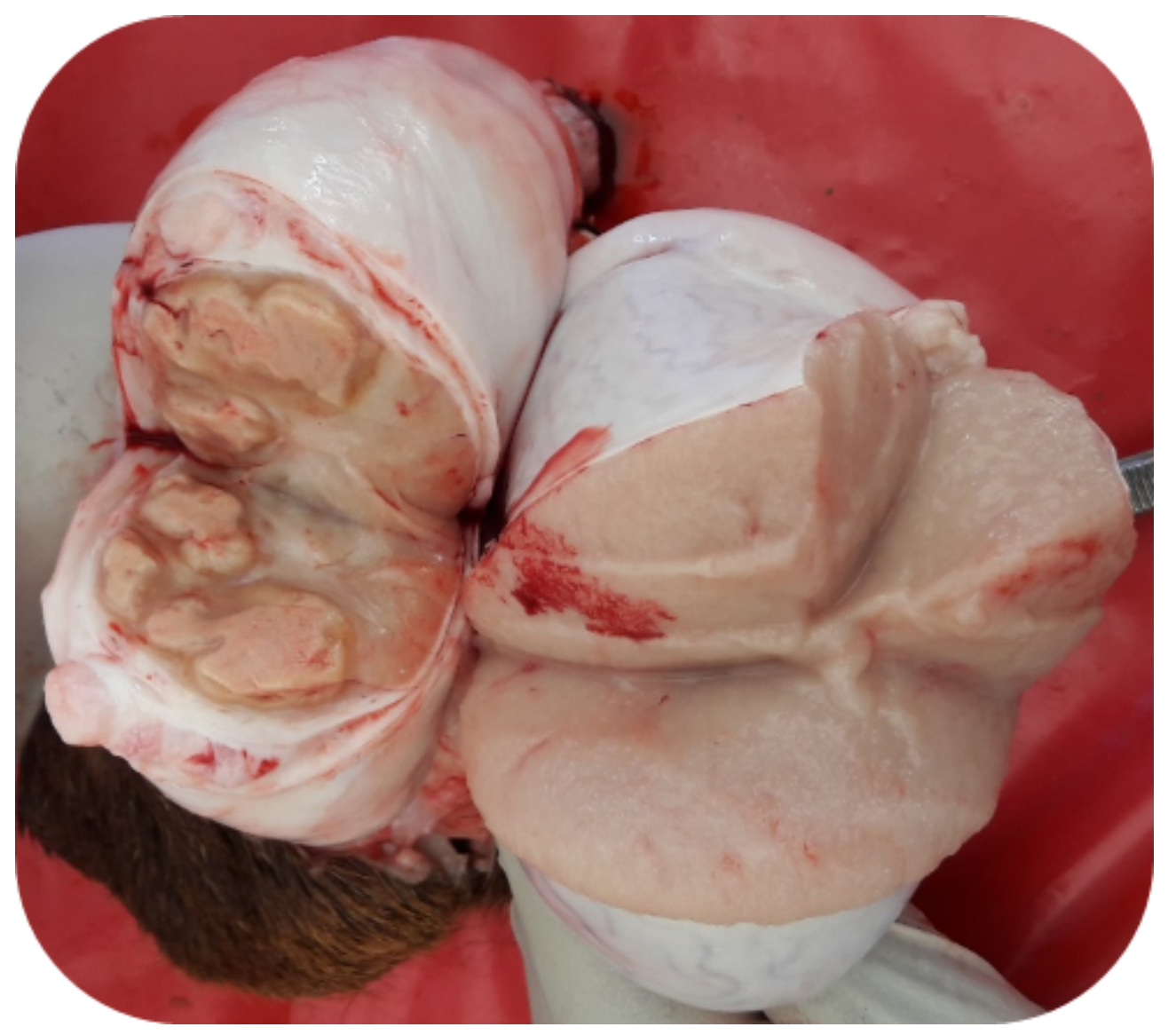

Figure 11

Left testicle with multiple necrotic cavities with nodular raised lesions in the testicular parenchyma with suppurative exudate. Epididymal spermatic granulomas.

\section{Figure 12}

Edematous fluid within the epididymis, the tunica vaginalis and the testicular parenchyma appears fibrotic. 


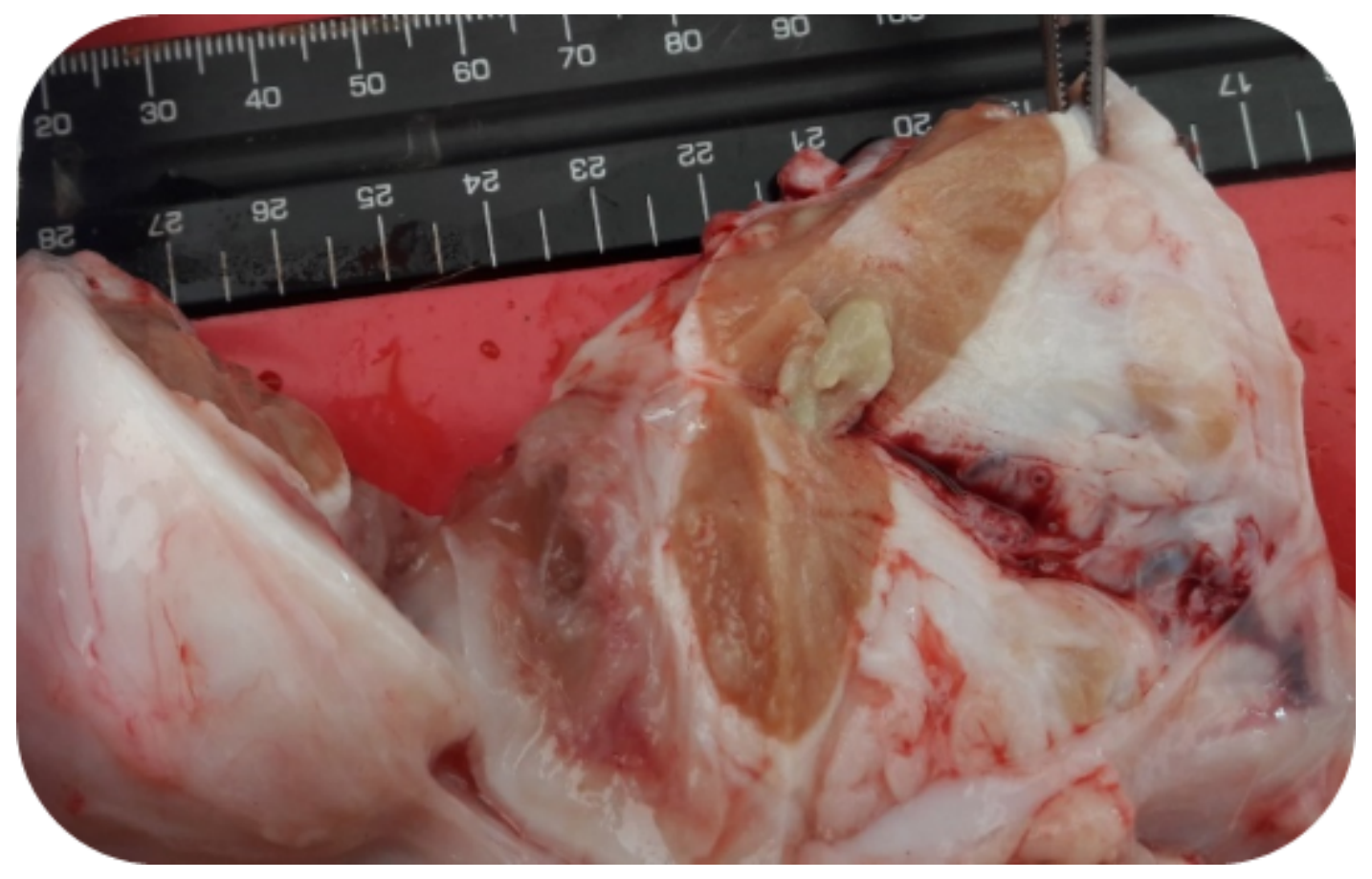

\section{Figure 13}

Focal necrotic lesion on the testicular parenchyma with caseous exudate. Hemorrhagic exudate of the epididymis head.

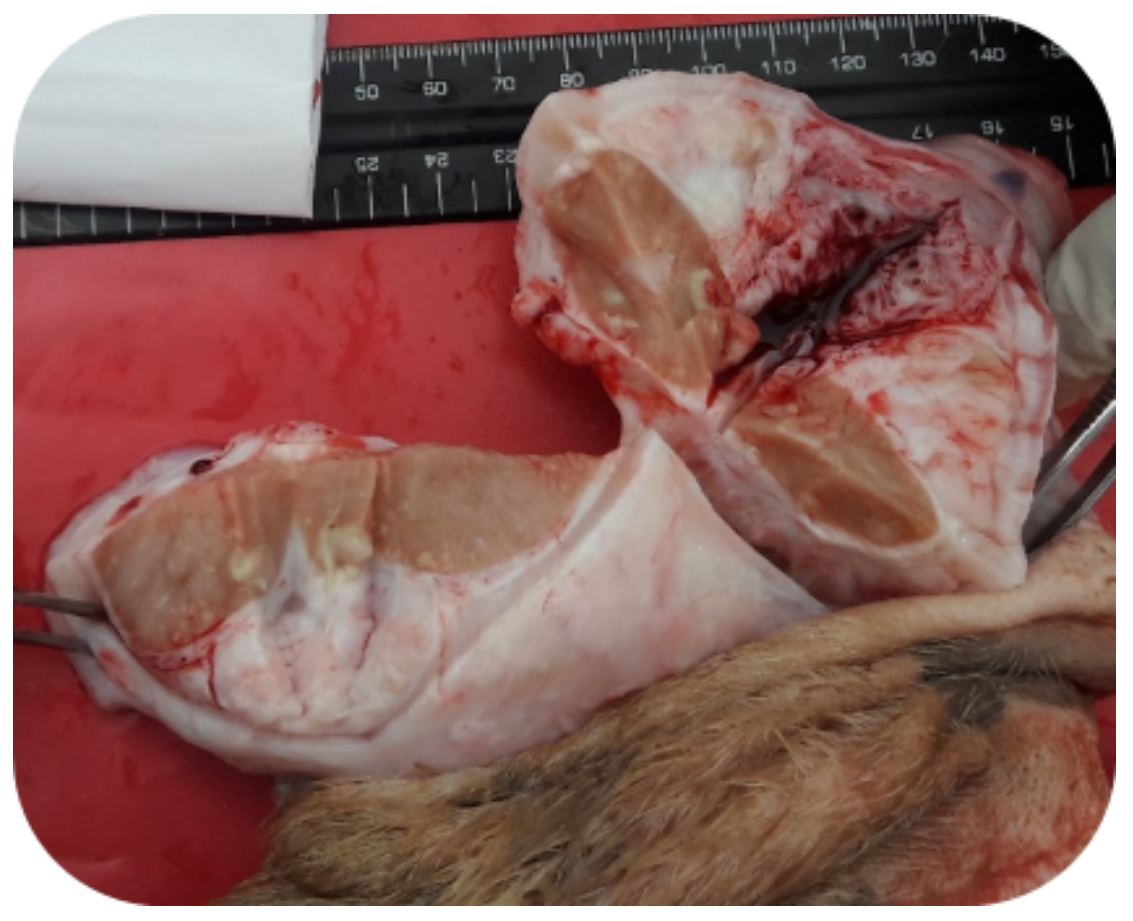

Figure 14

Hemorrhagic exudate of the epididymis head. Testicular parenchyma and tunica vaginalis fibrotic. 
Page 34/34 